\title{
Biogeochemical fluxes and fate of diazotroph-derived nitrogen in the food web after a phosphate enrichment: modeling of the VAHINE mesocosms experiment
}

\author{
Audrey Gimenez ${ }^{1}$, Melika Baklouti ${ }^{1}$, Sophie Bonnet ${ }^{1,2}$, and Thierry Moutin ${ }^{1}$ \\ ${ }^{1}$ Aix Marseille Université, Université de Toulon, CNRS, IRD, Mediterranean Institute of Oceanography \\ (MIO), Marseille, France \\ ${ }^{2}$ Institut de Recherche pour le Développement (IRD), AMU/CNRS/INSU, Université de Toulon, Mediterranean \\ Institute of Oceanography (MIO) UM110, 98848 Nouméa, New Caledonia
}

Correspondence to: Audrey Gimenez (audrey.gimenez@mio.osupytheas.fr)

Received: 7 December 2015 - Published in Biogeosciences Discuss.: 18 January 2016

Revised: 8 May 2016 - Accepted: 9 August 2016 - Published: 14 September 2016

\begin{abstract}
The VAHINE mesocosm experiment in the oligotrophic waters of the Nouméa lagoon (New Caledonia), where high $\mathrm{N}_{2}$ fixation rates and abundant diazotroph organisms were observed, aimed to assess the role of the nitrogen input through $\mathrm{N}_{2}$ fixation in carbon production and export and to study the fate of diazotroph-derived nitrogen (DDN) throughout the planktonic food web. A 1-D vertical biogeochemical mechanistic model was used in addition to the in situ experiment to enrich our understanding of the dynamics of the planktonic ecosystem and the main biogeochemical carbon $(\mathrm{C})$, nitrogen $(\mathrm{N})$ and phosphate $(\mathrm{P})$ fluxes. The mesocosms were intentionally enriched with $\sim 0.8 \mu \mathrm{mol} \mathrm{L}-1$ of inorganic $\mathrm{P}$ to trigger the development of diazotrophs and amplify biogeochemical fluxes. Two simulations were run, one with and the other without the phosphate enrichment. In the P-enriched simulation, $\mathrm{N}_{2}$ fixation, primary production (PP) and C export increased by 201, 208 and $87 \%$, respectively, consistent with the trends observed in the mesocosms $\left(+124,+141\right.$ and $+261 \%$ for $\mathrm{N}_{2}$ fixation, PP and $\mathrm{C}$ export, respectively). In total, 5-10 days were necessary to obtain an increase in primary and export productions after the dissolved inorganic phosphate (DIP) enrichment, thereby suggesting that classical methods (short-term microcosms experiments) used to quantify nutrient limitations of primary production may not be relevant. The model enabled us to monitor the fate of fixed $\mathrm{N}_{2}$ by providing the proportion of DDN in each compartment (inorganic and organic) of the model over time. At the end of the simulation (25 days), $43 \%$ of
\end{abstract}

the DDN was found in the non-diazotroph organisms, $33 \%$ in diazotrophs, $16 \%$ in the dissolved organic nitrogen pool, $3 \%$ in the particulate detrital organic pool and $5 \%$ in traps, indicating that $\mathrm{N}_{2}$ fixation was of benefit to non-diazotrophic organisms and contributed to $\mathrm{C}$ export.

\section{Introduction}

Dinitrogen $\left(\mathrm{N}_{2}\right)$ fixation is the major external source of new nitrogen $(\mathrm{N})$ for the upper ocean (Gruber and Galloway, 2008; Mahaffey et al., 2005) and particularly in the southwestern Pacific Ocean (Raimbault and Garcia, 2008; Moutin et al., 2008), which is recognized as one of the highest $\mathrm{N}_{2}$ fixation area in the global ocean (Luo et al., 2012; Bonnet et al., 2015). While $\mathrm{N}$ availability primarily controls autotrophic plankton growth in low-nutrient low-chlorophyll (LNLC) ecosystems (Moore et al., 2001a; Graziano et al., 1996), the new $\mathrm{N}$ sources provided by $\mathrm{N}_{2}$ fixation may drive the planktonic ecosystem from $\mathrm{N}$ limitation toward $\mathrm{P}$ limitation and may potentially affect the magnitude of $\mathrm{C}$ fixation and eventually $\mathrm{C}$ export through the so called $\mathrm{N}_{2}$-primed prokaryotic C pump (Karl et al., 2003, 2012). Consequently, it is important to quantify $\mathrm{N}$ fluxes to the ocean as well as to study the fate of $\mathrm{N}$ newly fixed by diazotrophs (or diazotrophderived $\mathrm{N}$, hereafter referred to as DDN) in order to understand how $\mathrm{N}_{2}$ fixation affects nutrient cycles and productivity in the ocean. 
Biogeochemical models including $\mathrm{N}_{2}$ fixation have been developed over the last decades, some of them including diazotrophic organisms as state variables as described below. In these models, Trichodesmium is the most frequently represented organism since it is the most studied diazotroph and its physiology is well documented in the literature (Moore et al., 2001b; Fennel et al., 2001; Moore et al., 2004; Rabouille et al., 2006). In recent studies, other diazotrophs such as unicellular Cyanobacteria (termed UCYN) or diatom-diazotroph associations (termed DDAs) have been implemented in biogeochemical models. This was first done by Goebel et al. (2007), who developed a diagnostic model to assess the relative contribution of three distinct diazotrophs (i.e., Trichodesmium sp. and two UCYN from Group A and Group B - UCYN-A and UCYN-B, respectively), at the tropical North Pacific station ALOHA. More recently, other biogeochemical models including a more complex planktonic food web and the contribution of Trichodesmium sp. DDAs, UCYN-A and UCYN-B were developed (Monteiro et al., 2010, 2011), together with models representing Trichodesmium sp., and a general group of UCYN (Dutkiewicz et al., 2012). Although increasing numbers of models include diazotrophic organisms as part of the food web, none of them have yet focused on the fate of DDN throughout the ecosystem. Diazotrophs release part of the recently fixed $\mathrm{N}_{2}$ as dissolved organic $\mathrm{N}$ (DON) and ammonium $\left(\mathrm{NH}_{4}^{+}\right)$ in the dissolved pool (Glibert and Bronk, 1994; Mulholland et al., 2006). The magnitude of this release (10 to $80 \%)$ is still under debate in the scientific community (Glibert and Bronk, 1994; Konno et al., 2010; Benavides et al., 2013b, a) and seems to depend on the physiological state of the cells (Berthelot et al., 2015a) as well as on exogenous factors such as viral lysis (Hewson et al., 2004) or sloppy feeding (O'Neil et al., 1996). Nevertheless, recent methods coupling ${ }^{15} \mathrm{~N}_{2}$ isotopic labeling, cell sorting by flow cytometry and high-resolution nanometer-scale secondary ion mass spectrometry (nanoSIMS) analyses enable the quantification of the DDN transfer from diazotrophs to specific groups of nondiazotrophic phytoplankton and bacteria, indicating that the DDN released in the dissolved pool is available and actively used by surrounding non-diazotrophic communities (Bonnet et al., 2016a).

The aim of the VAHINE project was to investigate the fate of DDN in oligotrophic ecosystems by deploying largevolume $\left(\sim 50 \mathrm{~m}^{3}\right)$ mesocosms to isolate a water mass with diazotrophs and by combining both field biogeochemical and planktonic diversity measurements and a mechanistic modeling approach. The New Caledonian (Nouméa) lagoon is considered an oligotrophic ecosystem influenced by oceanic waters inflowing from outside the lagoon (Ouillon et al., 2010). It supports high $\mathrm{N}_{2}$ fixation rates $\left(235 \mu \mathrm{mol} \mathrm{N} \mathrm{m} \mathrm{m}^{-2} \mathrm{~d}^{-1}\right.$; Garcia et al., 2007), high Trichodesmium sp. (Dupouy et al., 2000; Rodier and Le Borgne, 2008, 2010) and UCYN abundances (Biegala and Raimbault, 2008). This site therefore represented an ideal location to investigate the fate of DDN.
The mesocosms were intentionally enriched with dissolved inorganic phosphate (DIP) to enhance the potential development of $\mathrm{N}_{2}$ fixers in the mesocosms and therefore amplify $\mathrm{N}_{2}$ fixation fluxes and facilitate the study of DDN pathways in the planktonic ecosystem. Complementary field approaches were used during the VAHINE project including a $\delta_{15} \mathrm{~N}$ budget to assess the dominant source of $\mathrm{N}$ (from $\mathrm{NO}_{3}^{-}$and/or $\mathrm{N}_{2}$ fixation) fueling export production throughout the experiment (Knapp et al., 2016). Bonnet et al. (2016a) explored the fate of DDN on shorter timescales, investigating the relative contribution of each diazotroph phylotype to direct $\mathrm{C}$ export and quantifying the DDN release and its subsequent transfer to different groups of plankton by using nanoSIMS. In the present study, we developed a 1-D vertical biogeochemical model including the representation of Trichodesmium and UCYN diazotrophs of Group C (UCYN-C), which developed extensively during the mesocosm experiment (Turk-Kubo et al., 2015). The goal of this study was to enrich our understanding of the dynamics of the planktonic food web and the associated biogeochemical fluxes during the mesocosm experiment by providing information that could not be inferred through in situ measurements. We also used the model to track the route of DDN into the different compartments of the ecosystem (diazotrophs, nondiazotrophs, dissolved pool, detrital pool and export).

\section{Methods}

\subsection{The VAHINE experiment}

The VAHINE experiment took place in January-February 2013 (austral summer) in the oligotrophic New Caledonian lagoon. Three large-volume $\left(\sim 50 \mathrm{~m}^{3}, 15 \mathrm{~m}\right.$ height $)$ mesocosms equipped with sediment traps fixed at their bottom were deployed, and the dynamics of the three mesocosms were monitored for 23 days. A full description of the design and deployment of the mesocosms, including the selection of the study site and logistics, is provided in Bonnet et al. (2016b). The mesocosms were enriched with $\sim 0.8 \mu \mathrm{mol} \mathrm{L}-1$ of orthophosphate $\left(\mathrm{PO}_{4}^{3-}\right)$ on the evening of day 4 to alleviate any potential DIP limitation, which is a constant feature observed in the southwestern Pacific (Moutin et al., 2005, 2008), and to stimulate $\mathrm{N}_{2}$ fixation. Seawater was sampled daily in the three mesocosms (hereafter called M1, M2 and M3) and outside (hereafter called lagoon waters) at three depths (1, 6 and $12 \mathrm{~m})$, and the sediment traps and the material they contained were collected every $24 \mathrm{~h}$ by scuba divers. It should be noted that the term "export" used hereafter does not correspond to the material exported throughout the euphotic zone but to the sinking flux observed in the experiment at $15 \mathrm{~m}$ depth. The methods used to measure the different variables ( $\mathrm{C}, \mathrm{N}$ and $\mathrm{P}$ pools and fluxes, chlorophyll $a$ stocks, and plankton abundances) used in the present paper for comparison with the model simulations are detailed in the 
companion papers of Berthelot et al. (2015b), Leblanc et al. (2016) and Van Wambeke et al. (2016).

\subsection{Mesocosm modeling and hypothesis}

The model used in the VAHINE project is embedded in the modular numerical tool Eco3M (Baklouti et al., 2006), which uses mechanistic formulations to describe the biogeochemical processes engaged in the dynamics of marine pelagic ecosystems. Eco3M provides high flexibility by allowing its users to remove or add variables or processes to better adapt the model to a specific study. The VAHINE experiment consisted in the deployment of three replicate mesocosms in New Caledonia. Each mesocosm was modeled through a 1-D box model with 14 boxes of $1 \mathrm{~m}$ height each. Mass transfer between boxes is only allowed through sinking of particulate matter. Until day 10, only the detrital particles were allowed to sink but after this date, $10 \%$ of all the living and nonliving dissolved and particulate compartments were allowed to sink. The aim was to represent the setting of the aggregation process and the subsequent intensification of the sinking process. The aggregation process was indeed supposed to be favored, not only by the reduced eddy fluxes due to the containment of water but also by the release of transparent exopolymer particles (TEPs) as mentioned in Berman-Frank et al. (2016). At the bottom of the modeled mesocosms, the sinking material was accumulated to be compared with the particulate matter collected daily in the traps. Sinking velocities were not measured during the experiment, and the matter collected daily in traps was used to parameterize the sinking velocity . The latter is therefore set at a constant $0.7 \mathrm{~m} \mathrm{~d}^{-1}$ until day 10 and increases through the polynomial function given by Eq. (1) to reach $10 \mathrm{~m} \mathrm{~d}^{-1}$ at the end of the simulation:

$$
\begin{aligned}
& V=\alpha \cdot t^{10}+\beta, \\
& \alpha=\frac{\left(V_{\max }-V_{\min }\right)}{t_{\text {end }}{ }^{10}-t_{\text {ini }}{ }^{10}}, \\
& \beta=V_{\text {min }}-\alpha \cdot t_{\text {ini }}{ }^{10}
\end{aligned}
$$

where $V$ is the sinking velocity, $V_{\min }$ and $V_{\max }$ are, respectively, the minimum and maximum sinking velocities $(0.7$ and $\left.10 \mathrm{~m} \mathrm{~d}^{-1}\right), t$ is time, $t_{\text {ini }}$ is the moment at which the sinking rate starts to increase (i.e., day 10) and $t_{\text {end }}$ is the final day of the run (i.e., day 25). Bonnet et al. (2016b) reported that the VAHINE data revealed that the water column inside the mesocosms was well mixed, probably through natural convection at night. This feature is simply modeled through a vertical homogenization of every concentration once a day (at midnight), by imposing the vertically averaged concentrations in each box. Light irradiance data from the nearest meteorological station (Nouméa airport) were used for the surface irradiance in the model, and a vertical gradient was simulated on the basis of a classical Beer-Lambert law using the attenuation coefficient found in Morel (1988). When the total $\mathrm{N}$ an $\mathrm{P}$ pools $\left(\mathrm{N}_{\text {total }}\right.$ and $\left.\mathrm{P}_{\text {total }}\right)$ were calculated from the model outputs and compared to those obtained in situ, a significant difference appeared regarding $\mathrm{P}_{\text {total }}$, while the $\mathrm{N}_{\text {total }}$ fitted well (data not shown). This gap was mainly due to a DIP concentration that was too high compared to data, indicating a non-total consumption by organisms (not shown). To deal with this DIP excess in the system, a loss of DIP was added to the model. The main hypothesis to explain this DIP loss without a similar loss in DIN is the formation of a biofilm of $\mathrm{N}_{2}$-fixing organisms on the walls of the mesocosms (see Knapp et al., 2016, for details and DIP consumption calculations by the biofilm). Based on the calculations of Knapp et al. (2016), this loss was estimated at $10 \% \mathrm{~d}^{-1}$ and was assumed to have no influence on primary, bacterial or export production.

\subsection{The biogeochemical model}

The biogeochemical model used in this study is based on the Eco3M-MED model used for the Mediterranean Sea (Alekseenko et al., 2014). The only modification made on this previous version lies in the addition of diazotrophs and $\mathrm{N}_{2}$ fixation process to adapt the model to the VAHINE experiment. The model includes eight planktonic functional types (PFTs): four primary producers (autotrophic phytoplankton), three consumers (zooplankton) and one decomposer (heterotrophic bacteria, BAC). All of them are represented in terms of several concentrations $(\mathrm{C}, \mathrm{N}$ and $\mathrm{P}$ and chlorophyll concentrations for phytoplankton) and abundances (cells or individual per liter; Mauriac et al., 2011).

Phytoplankton was originally divided into two size classes, namely the large phytoplankton ( $\geq 10 \mu \mathrm{m}$; PHYL) and the small phytoplankton $(\leq 10 \mu \mathrm{m}$; PHYS $)$. The two $\mathrm{N}_{2}-$ fixing organisms are also distinguished by their size, the large one representing Trichodesmium sp. (TRI) and the small one Cyanothece sp. (UCYN-C), which strongly developed in the mesocosms during the experiment (Turk-Kubo et al., 2015). The zooplankton compartment is also divided into the three size classes nano-, micro- and mesozooplankton, which, respectively, represent heterotrophic nanoflagellates (HNF), ciliates (CIL) and copepods (COP). The latter is represented in terms of abundance and $\mathrm{C}, \mathrm{N}$ and $\mathrm{P}$ concentration. This differs from the model described in Alekseenko et al. (2014), in which mesozooplankton is only represented through an abundance and a $\mathrm{C}$ concentration. Three nutrients are considered, namely nitrate $\left(\mathrm{NO}_{3}^{-}\right)$, ammonium $\left(\mathrm{NH}_{4}^{+}\right)$ and phosphate (DIP). The dissolved organic pool (DOM) is composed of labile and semi-labile fractions of DOC (LDOC and SLDOC) and labile fractions of DON and dissolved organic phosphate (DOP). The refractory organic pools are not represented. Finally, the detrital particulate matter is represented in terms of $\mathrm{C}, \mathrm{N}$ and $\mathrm{P}\left(\operatorname{Det}_{\mathrm{C}}, \operatorname{Det}_{\mathrm{N}}\right.$ and DetP). All the biogeochemical processes and interactions between the state variables are described in Fig. 1. Except for the new 


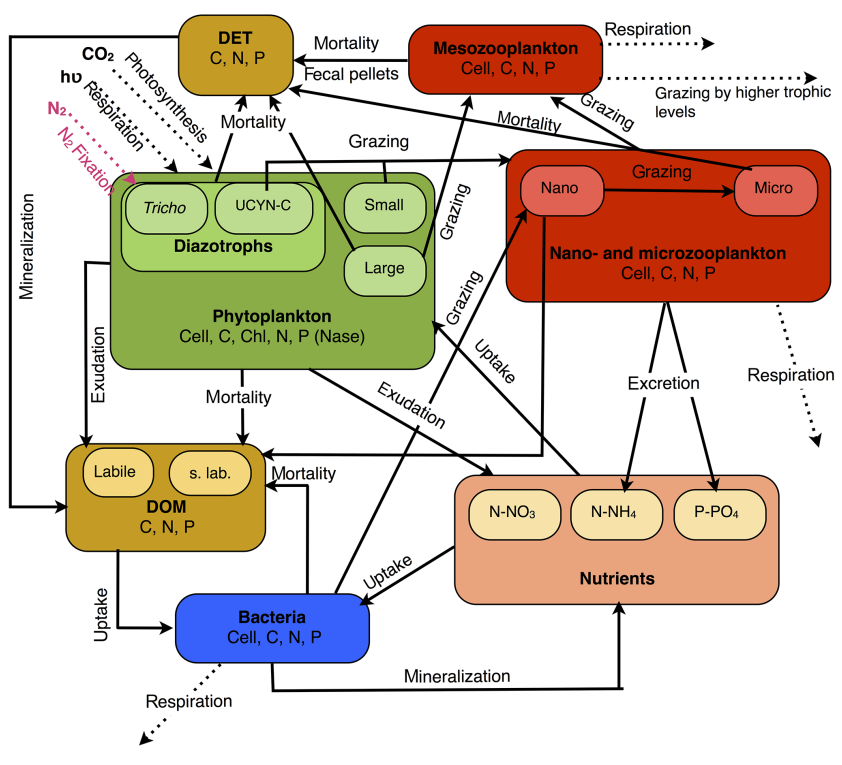

Figure 1. Conceptual diagram of the biogeochemical model for the $1-\mathrm{D}$ vertical model used in the VAHINE experiment.

parameters associated with the new features of the model as compared to the original one (Alekseenko et al., 2014), the parameters in common between the two model versions are identical.

\subsubsection{Initial conditions}

Initial values for the model state variables were derived from the in situ measurements averaged over the three mesocosms and the three sampling depths (1, 6, $12 \mathrm{~m})$.

Measured DOM values included the refractory organic matter, while the model only represents the labile (and semi-labile for $\mathrm{C}$ ) fraction. To extract the labile fraction from the DON data, we assumed that the plateau reached by the DON concentration at the end of the experiment (4 $\mu \mathrm{mol} \mathrm{L}^{-1}$ ) was equal to the concentration of the refractory DON in this study. Considering that the refractory fraction of DON was stable throughout the experiment and fixed at $4 \mu \mathrm{mol} \mathrm{L}{ }^{-1}$, from an initial total concentration of $5 \mu \mathrm{mol} \mathrm{L}{ }^{-1}$ at day 2, the initial labile fraction was therefore estimated at $1 \mu \mathrm{mol} \mathrm{L}{ }^{-1}$. The percentage of the labile portion over the total DON was calculated and then applied to DOP to estimate the initial concentration of labile DOP. The available DOC fraction (LDOC + SLDOC) was evaluated at $5 \mu \mathrm{mol} \mathrm{L}^{-1}$ in the equatorial Pacific (Pakulski and Benner, 1994). PHYL was initialized with diatom data and PHYS with the sum of nanoeukaryotes, picoeukaryotes, Synechococcus sp. and Prochlorococcus sp. The initial detrital particulate matter was derived by subtracting the total living particulate matter considered in the model form the total particulate matter measured in situ. Due to the lack of data for nano- and microzooplankton, we initiated HNF and CIL abundances us- ing $\mathrm{BAC} / \mathrm{HNF}$ and CIL / HNF abundance ratios from the literature, as this was made with the Eco3M-MED model for the Mediterranean (Alekseenko et al., 2014). Several ratios were tested in the range of those reported by Tanaka and Rassoulzadegan (2002) and Christaki et al. (2011), and the ones providing the best model outputs were used (Table 1).

The standard value of 0.5 ind $\mathrm{L}^{-1}$ was used for adult $\mathrm{COP}_{\text {ind }}$ which is consistent with the recent results of Hunt et al. (2016). The initial values of $\mathrm{C}, \mathrm{N}$ and $\mathrm{P}$ and chlorophyll concentrations for the planktonic compartments were derived from the initial cellular abundance data and from arbitrarily fixed intracellular contents (Table 1). These intracellular contents were thus taken from the Eco3M-MED model (Alekseenko et al., 2014).

\subsubsection{Modeling $\mathrm{N}_{2}$ fixation}

The mathematical formulation (see Eq. 4) used to represent $\mathrm{N}_{2}$ fixation was adapted from Rabouille et al. (2006) in order to be compatible with the formal features of the present model. It describes the $\mathrm{N}_{2}$ fixation flux as a function of the nitrogenase (i.e., the enzyme catalyzing $\mathrm{N}_{2}$ fixation) activity (Nase) and the diazotroph abundance (DIAZO cell, where DIAZO either refers to TRI or UCYN-C). The $\mathrm{N}_{2}$ fixation flux is regulated by the intracellular $\mathrm{C}$ quota and the $\mathrm{N}: \mathrm{C}$ and $\mathrm{P}: \mathrm{C}$ ratios (Eq. 8) and by the intracellular $\mathrm{N}$ quota and $\mathrm{N}$ : C ratio (Eq. 9). Intracellular $\mathrm{N}$ quota controls the net $\mathrm{N}_{2}$ fixation rate through a quota function $\left(1-f_{Q_{N}}\right.$, Eq. 9$)$, the $\mathrm{N}$ excess exuded being equally distributed into the DON and $\mathrm{NH}_{4}^{+}$pools. As in Rabouille et al. (2006), the nitrogenase activity (Nase, in mol Ncell ${ }^{-1} \mathrm{~s}^{-2}$ ) is a state variable, the dynamics of which are described in Eq. (5). The nitrogenase activity results from the balance between the increase and the decrease in its activity. The increase in the potential nitrogenase activity is assumed to be controlled by the $\mathrm{N}$ intracellular quota (Eq. 6) and by the $\mathrm{NO}_{3}^{-}$concentration in the field (Eq. 7). Trichodesmium are non-heterocystous filamentous cyanobacteria with differentiated cells, called diazocysts, located in the center part of the colony (Bergman and Carpenter, 1991), where $\mathrm{N}_{2}$ fixation occurs. This spatial segregation mechanism is used by the organism to protect the nitrogenase enzyme from oxygen inactivation produced by photosynthesis (Carpenter and Price, 1976; Bryceson and Fay, 1981). In addition, Trichodesmium combines spatial and temporal segregation to maximize the protection of the nitrogenase. This therefore allows the cells to fix $\mathrm{N}_{2}$ for only a few hours in the daytime at around noon (Roenneberg and Carpenter, 1993; El-Shehawy, 2003; Berman-Frank et al., 2001). In contrast, Reddy et al. (1993) have shown that UCYN-C can only use a temporal strategy to separate $\mathrm{N}_{2}$ fixation and photosynthesis processes and thus need to fix $\mathrm{N}_{2}$ to protect the nitrogenase from $\mathrm{O}_{2}$, released by photosynthesis during the day. The inhibition of $\mathrm{N}_{2}$ fixation during the day for UCYN-C and during the night for TRI is simulated by the $f_{\text {inhib }}$ function which controls the nitrogenase activity (Eq. 10; $12 \mathrm{~h}$ lagged 
Table 1. Initial conditions for the biogeochemical model.

\begin{tabular}{|c|c|c|c|c|c|c|c|}
\hline State variable & Reference & Value & Unit & State variable & Reference & Value & Unit \\
\hline $\mathrm{BAC}_{\text {cell }}$ & Data & $4.75 \times 10^{8}$ & Cell $\mathrm{L}^{-1}$ & $\mathrm{HNF}_{\text {cell }}$ & $\frac{\mathrm{BAC}_{\text {cell }}}{50}$ & $9.519 \times 10^{6}$ & ind $L^{-1}$ \\
\hline $\mathrm{BAC}_{\mathrm{C}}$ & $\mathrm{BAC}_{\text {cell }} \times Q_{\mathrm{C}}^{\max }$ & 1.152 & $\mu \mathrm{mol} \mathrm{CL}^{-1}$ & $\mathrm{HNF}_{\mathrm{C}}$ & $\mathrm{HNF}_{\text {cell }} \times Q_{\mathrm{C}}^{\max }$ & 34.950 & $\mu \mathrm{mol} \mathrm{CL}{ }^{-1}$ \\
\hline $\mathrm{BAC}_{\mathrm{N}}$ & $\mathrm{BAC}_{\text {cell }} \times Q_{\mathrm{N}}^{\text {moy }} \times 0.7$ & 0.107 & $\mu \mathrm{mol} \mathrm{N} \mathrm{L}{ }^{-1}$ & $\mathrm{HNF}_{\mathrm{N}}$ & $\mathrm{HNF}_{\text {cell }} \times Q_{\mathrm{N}}^{\text {moy }} \times 0.7$ & 0.326 & $\mu \mathrm{mol} \mathrm{N} \mathrm{L}-1$ \\
\hline $\mathrm{BA} C_{\mathrm{P}}$ & $\mathrm{BAC}_{\mathrm{cell}} \times Q_{\mathrm{P}}^{\min }$ & 0.007 & $\mu \mathrm{mol} \mathrm{PL}^{-1}$ & $\mathrm{HNF}_{\mathrm{P}}$ & $\mathrm{HNF}_{\text {cell }} \times Q_{\mathrm{P}}^{\min }$ & 0.023 & $\mu \mathrm{mol} \mathrm{PL} \mathrm{P}^{-1}$ \\
\hline $\mathrm{CIL}_{\text {cell }}$ & $\frac{\mathrm{HNF}_{\text {cell }}}{2500}$ & 3808 & ind $\mathrm{L}^{-1}$ & $\mathrm{COP}_{\text {cell }}$ & Adapted data & 0.5 & ind $\mathrm{L}^{-1}$ \\
\hline $\mathrm{CIL}_{\mathrm{C}}$ & $\mathrm{CIL}_{\text {cell }} \times Q_{\mathrm{C}}^{\max }$ & 1.538 & $\mu \mathrm{mol} \mathrm{CL}^{-1}$ & $\mathrm{COP}_{\mathrm{C}}$ & $\mathrm{COP}_{\text {cell }} \times Q_{\mathrm{C}}^{\max }$ & 0.350 & $\mu \mathrm{mol} \mathrm{C} \mathrm{L}{ }^{-1}$ \\
\hline $\mathrm{CIL}_{\mathrm{N}}$ & $\mathrm{CIL}_{\text {cell }} \times Q_{\mathrm{N}}^{\text {moy }} \times 0.7$ & 0.108 & $\mu \mathrm{molN} \mathrm{L}{ }^{-1}$ & $\mathrm{COP}_{\mathrm{N}}$ & $\mathrm{COP}_{\text {cell }} \times Q_{\mathrm{N}}^{\text {moy }} \times 0.7$ & 0.042 & $\mu \mathrm{molNL} \mathrm{L}^{-1}$ \\
\hline $\mathrm{CIL}_{\mathrm{P}}$ & $\mathrm{CIL}_{\text {cell }} \times Q_{\mathrm{P}}^{\min }$ & 0.005 & $\mu \mathrm{mol} \mathrm{PL}^{-1}$ & $\mathrm{COP}_{\mathrm{P}}$ & $\mathrm{COP}_{\text {cell }} \times Q_{\mathrm{P}}^{\min }$ & 0.002 & $\mu \mathrm{mol} \mathrm{PL}{ }^{-1}$ \\
\hline PHYL $_{\text {cell }}$ & Data & $4.48 \times 10^{4}$ & Cell $\mathrm{L}^{-1}$ & PHYS $_{\text {cell }}$ & Data & $8.11 \times 10^{7}$ & Cell $\mathrm{L}^{-1}$ \\
\hline PHYL $_{\mathrm{C}}$ & PHYL $_{\text {cell }} \times Q_{\mathrm{C}}^{\max }$ & 0.306 & $\mu \mathrm{mol} \mathrm{CL}^{-1}$ & PHYS $_{\mathrm{C}}$ & PHYS $_{\text {cell }} \times Q_{\mathrm{C}}^{\max }$ & 1.664 & $\mu \mathrm{mol} \mathrm{CL}^{-1}$ \\
\hline $\mathrm{PHYL}_{\mathrm{N}}$ & PHYL $_{\text {cell }} \times Q_{\mathrm{N}}^{\text {moy }} \times 0.7$ & 0.022 & $\mu \mathrm{mol} \mathrm{N} \mathrm{L}{ }^{-1}$ & PHYS $_{N}$ & PHYS $_{\text {cell }} \times Q_{\mathrm{N}}^{\text {moy }} \times 0.7$ & 0.117 & $\mu \mathrm{mol} \mathrm{N} \mathrm{L}{ }^{-1}$ \\
\hline PHYLP & $\mathrm{PHYL}_{\text {cell }} \times Q_{\mathrm{P}}^{\min }$ & $9.634 \times 10^{-4}$ & $\mathrm{molPL}^{-1}$ & PHYSP & $\mathrm{PHYS}_{\text {cell }} \times Q_{\mathrm{P}}^{\min }$ & 0.005 & $\mu \mathrm{mol} \mathrm{PL}{ }^{-1}$ \\
\hline PHYL $_{\mathrm{Chl}}$ & $\frac{\text { PHYL }_{C}}{25}$ & 0.012 & $\mu \mathrm{g} \mathrm{Chl} \mathrm{L}{ }^{-1}$ & PHYS $_{\mathrm{Chl}}$ & $\frac{\text { PHYS }_{\mathrm{C}}}{12}$ & 0.138 & $\mu \mathrm{gChl} \mathrm{L}^{-1}$ \\
\hline UCYN-C & Data & 210 & Cell $\mathrm{L}^{-1}$ & TRI $_{\text {cell }}$ & Data & 180 & $\operatorname{trich} \mathrm{L}^{-1}$ \\
\hline $\mathrm{UCYN}-\mathrm{C}_{\mathrm{C}}$ & $\mathrm{UCYN}^{-\mathrm{C}_{\text {cell }}} \times Q_{\mathrm{C}}^{\max }$ & 4.308 & $\mathrm{pmol} \mathrm{CL}^{-1}$ & $\mathrm{TRI}_{\mathrm{C}}$ & $\mathrm{TRI}_{\text {cell }} \times Q_{\mathrm{C}}^{\max }$ & 0.123 & $\mu \mathrm{mol} \mathrm{CL}^{-1}$ \\
\hline $\mathrm{UCYN}-\mathrm{C}_{\mathrm{N}}$ & $\mathrm{UCYN}-\mathrm{C}_{\text {cell }} \times Q_{\mathrm{N}}^{\max }$ & 0.650 & $\mathrm{pmol} \mathrm{NL}^{-1}$ & $\mathrm{TRI}_{\mathrm{N}}$ & $\mathrm{TRI}_{\text {cell }} \times Q_{\mathrm{N}}^{\max }$ & 0.018 & $\mu \mathrm{mol} \mathrm{N} \mathrm{L}^{-1}$ \\
\hline $\mathrm{UCYN}-\mathrm{CP}_{\mathrm{P}}$ & $\mathrm{UCYN}-\mathrm{C}_{\text {cell }} \times Q_{\mathrm{P}}^{\min }$ & 0.013 & $\mathrm{pmol} \mathrm{PL}^{-1}$ & TRIP & $\mathrm{TRI}_{\text {cell }} \times Q_{\mathrm{P}}^{\min }$ & 0.388 & $\mathrm{nmol} \mathrm{PL}^{-1}$ \\
\hline UCYN-C Nase & $\frac{\text { TRI }_{\text {Nase }}}{33300}$ & $1.9 \times 10^{20}$ & $\operatorname{mol~N}$ cell $^{-1} \mathrm{~s}^{-1}$ & $\mathrm{TRI}_{\text {Nase }}$ & Rabouille et al. (2006) & $7.5 \times 10^{16}$ & molN trich $^{-1} \mathrm{~L}^{-1}$ \\
\hline UCYN-C & $\frac{U \mathrm{CYN}-\mathrm{C}_{\mathrm{C}}}{12}$ & 0.359 & $\operatorname{pgChl~L}{ }^{-1}$ & $\mathrm{TRI}_{\mathrm{Chl}}$ & $\frac{\text { TRI }_{C}}{25}$ & 0.005 & $\mu \mathrm{g} \mathrm{Chl} \mathrm{L}-1$ \\
\hline Labile DOC & Data & 0.25 & $\mu \mathrm{mol} \mathrm{CL}^{-1}$ & POC $C_{\text {Det }}$ & $\mathrm{POC}_{\mathrm{T}} \mathrm{T}-\mathrm{POC}_{\text {Living }}$ & 3.791 & $\mu \mathrm{mol} \mathrm{CL}^{-1}$ \\
\hline Semi-labile DOC & Labile DOC $\times 19$ & 4.75 & $\mu \mathrm{mol} \mathrm{CL}-1$ & $\mathrm{PON}_{\text {Det }}$ & $\mathrm{PON}_{\text {Tot }}-\mathrm{PON}_{\text {Living }}$ & 0.188 & $\mu \mathrm{mol} \mathrm{N} \mathrm{L}-1$ \\
\hline Labile DON & Data & 1.0 & $\mu \mathrm{mol} \mathrm{N} \mathrm{L}{ }^{-1}$ & POP $_{\text {Det }}$ & $\mathrm{POP}_{\text {Tot }}-\mathrm{POP}_{\text {Living }}$ & 0.012 & $\mu \mathrm{mol} \mathrm{PL}{ }^{-1}$ \\
\hline Labile DOP & Data & 0.0132 & $\mu \mathrm{mol} \mathrm{PL} \mathrm{L}^{-1}$ & & & & \\
\hline $\mathrm{NO}_{3}^{-}$ & Data & 53 & $\mathrm{nmol} \mathrm{L}^{-1}$ & & & & \\
\hline $\mathrm{NH}_{4}$ & Data & 36 & $\mathrm{nmol} \mathrm{L}^{-1}$ & & & & \\
\hline $\mathrm{PO}_{4}$ & Data & 30 & $\mathrm{nmol} \mathrm{L}^{-1}$ & & & & \\
\hline
\end{tabular}

between TRI and UCYN-C). The decrease in nitrogenase activity is regulated by a saturation function involving Nase $\mathrm{dec}_{\mathrm{max}}^{\max }$ and a coefficient of nitrogenase degradation (see Eq. (5) and Table 2). Both the increase and decrease in nitrogenase are energy dependent and controlled by the intracellular $\mathrm{C}$ quota (Eq. 8).

$$
\begin{aligned}
& \underbrace{\text { Flux }_{\mathrm{N}_{2}}}_{\text {mol NL }^{-1} \mathrm{~s}^{-1}}=\underbrace{\text { Nase }}_{\text {mol Neell }^{-1} \mathrm{~s}^{-1}} \times \underbrace{\text { DIAZO }_{\text {CELL }}}_{\text {cell L }} \times f_{Q_{\mathrm{C}}} \times\left(1-f_{Q_{\mathrm{N}}}\right)
\end{aligned}
$$

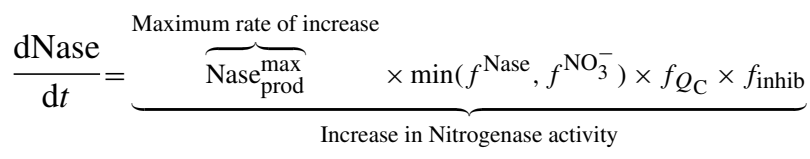

$$
\begin{aligned}
& -\underbrace{\overbrace{\text { Nase }_{\mathrm{dec}}^{\max }}^{\text {Maximum rate of decrease }} \times \frac{\text { Nase }}{\text { Nase }+K_{\text {Nase }}} \times f_{Q_{\mathrm{C}}}}
\end{aligned}
$$$$
\text { Decrease in Nitrogenase activity }
$$

$$
\begin{aligned}
f^{\mathrm{Nase}}= & \min \left(\max \left[\left(\frac{Q_{\mathrm{NC}}^{\max }-Q_{\mathrm{NC}}}{Q_{\mathrm{NC}}^{\max }-Q_{\mathrm{NC}}^{\min }}\right)^{0.06}, 0\right],\right. \\
& \left.\left(\frac{Q_{\mathrm{N}}^{\max }-Q_{\mathrm{N}}}{Q_{\mathrm{N}}^{\max }-Q_{\mathrm{N}}^{\min }}\right)^{0.06}, 1\right)
\end{aligned}
$$

$$
\begin{aligned}
& f^{\mathrm{NO}_{3}^{-}}=\frac{1}{1+\frac{\mathrm{NIT}}{K_{\mathrm{NO}_{3}^{-}}}} \\
& f_{Q_{\mathrm{C}}}=\max \left(\left[\left(\frac{Q_{\mathrm{NC}}^{\max }-Q_{\mathrm{NC}}}{Q_{\mathrm{NC}}^{\max }-Q_{\mathrm{NC}}^{\min }}\right)^{0.06}, 0\right]\right. \text {, } \\
& \max \left[\left(\frac{Q_{\mathrm{PC}}^{\max }-Q_{\mathrm{PC}}}{Q_{\mathrm{PC}}^{\max }-Q_{\mathrm{PC}}^{\min }}\right)^{0.06}, 0\right] \text {, } \\
& \left.\left(\frac{Q_{\mathrm{C}}-Q_{\mathrm{C}}^{\min }}{Q_{\mathrm{C}}^{\max }-Q_{\mathrm{C}}^{\min }}\right)^{0.06}, 1\right) \\
& f_{Q_{\mathrm{N}}}=\left\{\begin{array}{l}
\min \left\{1+\left|\frac{Q_{\mathrm{N}}^{\max }-Q_{\mathrm{N}}}{Q_{\mathrm{N}}^{\max }-Q_{\mathrm{N}}^{\min }}\right|^{0.06}, 2\right\} \text { if } Q_{\mathrm{N}} \geq Q_{\mathrm{N}}^{\max } \\
1-\left(\frac{Q_{\mathrm{NC}}^{\max }-Q_{\mathrm{NC}}}{Q_{\mathrm{NC}}^{\max }-Q_{\mathrm{NC}}^{\min }}\right)^{0.06} \text { if } Q_{\mathrm{N}} \in\left[Q_{\mathrm{N}}^{\min }, Q_{\mathrm{N}}^{\max }\right] \\
\operatorname{and} Q_{\mathrm{NC}}^{\min } Q_{\mathrm{NC}}^{\max } \\
\min \left\{1+\left|\frac{Q_{\mathrm{NC}}^{\max }-Q_{\mathrm{NC}}}{Q_{\mathrm{NC}}^{\max }-Q_{\mathrm{NC}}^{\min }}\right|^{0.06}, 2\right\} \text { else }
\end{array}\right. \\
& f_{\text {inhib }}=\exp (3.7(\cos (2 \pi t-\pi)-1))
\end{aligned}
$$

\subsubsection{Parametrization of diazotrophs and diazotrophs activity}

Trichodesmium sp. and unicellular cyanobacteria (Group C and especially Cyanothece sp.) exhibit distinct physiologies, sizes and morphologies. Regarding the parametrization of di- 
Table 2. Parameters added for the diazotroph organisms.

\begin{tabular}{|c|c|c|c|c|}
\hline Parameter & Definition & TRI value & UCYN-C value & Unit \\
\hline$Q_{\mathrm{C}}^{\min }$ & Minimum cell quota of $\mathrm{C}$ & $2.28 \times 10^{-10}$ & $6.84 \times 10^{-15}$ & $\mathrm{~mol} \mathrm{C} \mathrm{cell}^{-1}$ \\
\hline$Q_{\mathrm{C}}^{\max }$ & Maximum cell quota of $\mathrm{C}$ & $6.84 \times 10^{-15}$ & $2.05 \times 10^{-14}$ & mol C cell ${ }^{-1}$ \\
\hline$Q_{\mathrm{N}}^{\min }$ & Minimum cell quota of $\mathrm{N}$ & $3.44 \times 10^{-11}$ & $1.03 \times 10^{-15}$ & mol N cell ${ }^{-1}$ \\
\hline$Q_{\mathrm{N}}^{\max }$ & Maximum cell quota of $\mathrm{N}$ & $1.03 \times 10^{-10}$ & $3.09 \times 10^{-15}$ & mol $\mathrm{N} \mathrm{cell}^{-1}$ \\
\hline$Q_{\mathrm{P}}^{\min }$ & Minimum cell quota of $\mathrm{P}$ & $3.44 \times 10^{-11}$ & $1.03 \times 10^{-15}$ & mol N cell ${ }^{-1}$ \\
\hline$Q_{\mathrm{P}}^{\max }$ & Maximum cell quota of $\mathrm{P}$ & $1.03 \times 10^{-10}$ & $3.09 \times 10^{-15}$ & $\mathrm{~mol} \mathrm{~N} \mathrm{cell}^{-1}$ \\
\hline$Q_{\mathrm{CN}}^{\min }$ & Minimum cell $\mathrm{C}: \mathrm{N}$ ratio & 5.0 & 5.0 & $\operatorname{molC~} \mathrm{mol} \mathrm{N}^{-1}$ \\
\hline$Q_{\mathrm{CN}}^{\max }$ & Maximum cell $\mathrm{C}: \mathrm{N}$ ratio & 19.8 & 19.8 & $\operatorname{mol~C~mol~N}{ }^{-1}$ \\
\hline$Q_{\mathrm{CP}}^{\mathrm{min}}$ & Minimum cell $\mathrm{C}: \mathrm{P}$ ratio & 35.33 & 35.33 & $\mathrm{~mol} \mathrm{C} \mathrm{mol} \mathrm{P}-1$ \\
\hline$Q_{\mathrm{CP}}^{\max }$ & Maximum cell $\mathrm{C}: \mathrm{P}$ ratio & 318.0 & 318.0 & $\mathrm{~mol} \mathrm{C} \mathrm{mol} \mathrm{P}-1$ \\
\hline$\mu_{\max }$ & Maximum growth rate & $2.08 \times 10^{-6}$ & $3.2 \times 10^{-5}$ & $\mathrm{~s}^{-1}$ \\
\hline$k_{\mathrm{m}}$ & Specific natural mortality rate & $1.16 \times 10^{-6}$ & $1.16 \times 10^{-6}$ & $s^{-1}$ \\
\hline$K_{\mathrm{NO}^{3-}}$ & Half-saturation constant for $\mathrm{NO}^{3-}$ & $1.85 \times 10^{-6}$ & $7.6 \times 10^{-6}$ & $\mathrm{molL}^{-1}$ \\
\hline$V_{\mathrm{NO}^{3-}}^{\max }$ & Maximum uptake rate for $\mathrm{NO}^{3-}$ & $3.16 \times 10^{-15}$ & $9.91 \times 10^{-20}$ & mol cell ${ }^{-1} \mathrm{~s}^{-1}$ \\
\hline$K_{\mathrm{NH}^{4+}}$ & Half-saturation constant for $\mathrm{NH}^{4+}$ & $7.0 \times 10^{-6}$ & $1.69 \times 10^{-6}$ & $\mathrm{~mol} \mathrm{~L}^{-1}$ \\
\hline$V_{\mathrm{NH}^{4+}}^{\max }$ & Maximum uptake rate for $\mathrm{NH}^{4+}$ & $3.16 \times 10^{-15}$ & $9.91 \times 10^{-20}$ & mol cell ${ }^{-1} \mathrm{~s}^{-1}$ \\
\hline$K_{\mathrm{PO}_{4}^{3-}}$ & Half-saturation constant for $\mathrm{PO}_{4}^{3-}$ & $1.4 \times 10^{-6}$ & $2.62 \times 10^{-7}$ & $\mathrm{~mol} \mathrm{~L}^{-1}$ \\
\hline$V_{\mathrm{PO}_{4}^{3-}}^{\max }$ & Maximum uptake rate for $\mathrm{PO}_{4}^{3-}$ & $1.98 \times 10^{-16}$ & $6.19 \times 10^{-21}$ & mol cell ${ }^{-1} \mathrm{~s}^{-1}$ \\
\hline$K_{\mathrm{DON}}^{-4}$ & Half-saturation constant for DON & $4.32 \times 10^{-5}$ & $1.05 \times 10^{-5}$ & $\mathrm{~mol} \mathrm{~L}^{-1}$ \\
\hline$V_{\mathrm{DON}}^{\max }$ & Maximum uptake rate for DON & $3.16 \times 10^{-15}$ & $9.91 \times 10^{-20}$ & mol cell ${ }^{-1} \mathrm{~s}^{-1}$ \\
\hline$K_{\mathrm{DOP}}$ & Half-saturation constant for DOP & $3.4 \times 10^{-6}$ & $6.57 \times 10^{-7}$ & $\mathrm{~mol} \mathrm{~L}^{-1}$ \\
\hline$V_{\mathrm{DOP}}^{\max }$ & Maximum uptake rate for DOP & $3.16 \times 10^{-15}$ & $6.19 \times 10^{-21}$ & mol cell $^{-1} \mathrm{~s}^{-1}$ \\
\hline Nase $_{\text {prod }}^{\max }$ & $\begin{array}{l}\text { Maximum rate of increase } \\
\text { of nitrogenase activity }\end{array}$ & $1.17 \times 10^{-21}$ & $3.51 \times 10^{-26}$ & mol cell ${ }^{-1} \mathrm{~s}^{-2}$ \\
\hline Nase $\mathrm{e}_{\text {decr }}^{\max }$ & $\begin{array}{l}\text { Maximum rate of decay } \\
\text { of nitrogenase activity }\end{array}$ & $9.36 \times 10^{-22}$ & $2.83 \times 10^{-26}$ & mol cell ${ }^{-1} \mathrm{~s}^{-2}$ \\
\hline$K_{\text {Nase }}$ & Coefficient of nitrogenase degradation & $9.44 \times 10^{-16}$ & $1.92 \times 10^{-20}$ & mol cell ${ }^{-1} \mathrm{~s}^{-1}$ \\
\hline $\operatorname{cosT}_{\text {DIAZO }}$ & Respiration cost for nitrogen fixation & 1.5 & 1.5 & $\mathrm{~mol} \mathrm{~mol}^{-1}$ \\
\hline EXUD $_{\text {DON }}$ & Exudation part of $\mathrm{N}_{2}$ fixed towards DON & 0.5 & 0.5 & \\
\hline $\mathrm{EXUD}_{\mathrm{NH}_{4}}$ & Exudation part of $\mathrm{N}_{2}$ fixed towards $\mathrm{NH}_{4}$ & 0.5 & 0.5 & \\
\hline
\end{tabular}

azotrophs and the processes they undertake that they have in common with non-diazotrophs, it has arbitrarily been considered that Trichodesmium cells are equivalent to PHYL cells, and the TRI state variable was therefore parameterized like 100 PHYL cells (assuming that a trichome includes 100 cells; Luo et al., 2012), and UCYN-C were parameterized like PHYS. For the diazotrophy process, parameters for TRI were configured following the work of Rabouille et al. (2006). TRI was also hypothesized as not being grazed in the field. Its main predator is the copepods of the Harpacticoida order (mostly Macrosetella and Miracia; O'Neil and Roman, 1992), which are not found in significant numbers in the study area as reported in Hunt et al. (2016). To our knowledge, Grimaud et al. (2013) were the first to propose a dynamic model to depict the $\mathrm{N}_{2}$ fixation by unicellular cyanobacteria (UCYN-C, Crocosphaera watsonii). Nevertheless, since this formulation of $\mathrm{N}_{2}$ fixation was different from that of Rabouille et al. (2006), we were unable to use the parameters provided in Grimaud et al. (2013). The latter were therefore derived from that of TRI, not only on the basis of cell size considerations but to obtain overall agreement with $\mathrm{N}_{2}$ fixation fluxes measured during the experiment. All the parameters added for both TRI and UCYN-C new compartments are detailed in Table 2.

\subsection{The fate of fixed $\mathrm{N}_{2}$}

The main purpose of the DIP enrichment was to enhance diazotrophy in the mesocosms and facilitate the measurement of the DDN transfer. To monitor the pathways of DDN throughout the food web, a post-processing treatment was realized since the model itself does not allow a distinction to be made between the DDN and other $\mathrm{N}$ sources. The aim of the post-processing treatment was to dynamically calculate the DDN proportion in each compartment of the biogeochemical model. At the beginning of the simulation, we assumed that DDN was equal to zero in each compartment. 


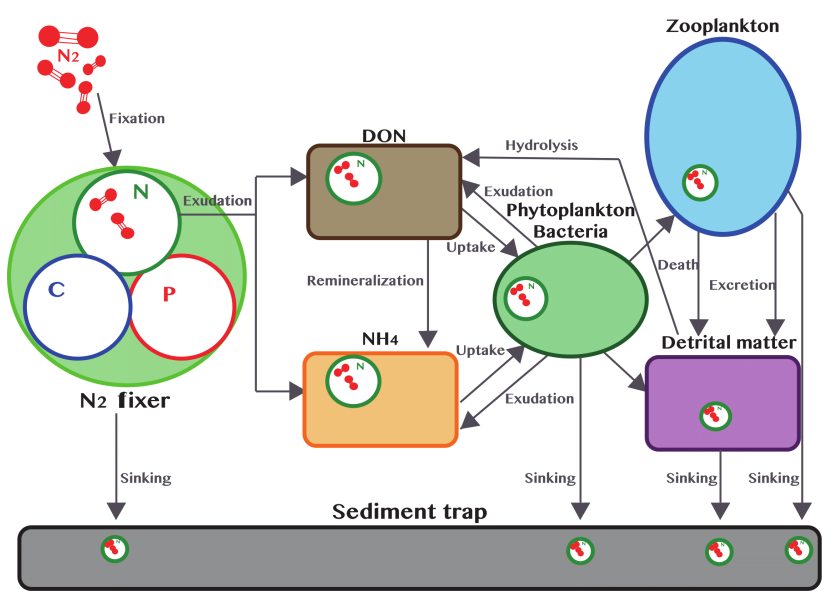

Figure 2. Conceptual diagram of the DDN pathway with compartments and processes engaged in the DDN transfer within the food web.

We further assumed that the ratio DDN / $\mathrm{N}$ in each $\mathrm{N}$ flux leaving a given compartment was the same as that within this compartment. DDN transfer starts with $\mathrm{N}$ exudation by diazotrophs. This DDN release fueled the DON and $\mathrm{NH}_{4}^{+}$compartments, which are then taken up by autotrophs and heterotrophs. Grazing by zooplankton on the lower trophic levels will then transfer part of the DDN by excretion, sloppy feeding and egestion of fecal pellets. Finally, remineralization and natural mortality will also contribute to the transfer of DDN through the planktonic food web. Figure 2 illustrates the different processes involved in the DDN transfer within the ecosystem.

\section{Results}

Two simulations of the mesocosm experiment were run: the first includes the representation of the DIP enrichment $\left(\mathrm{SIM}^{E}\right)$, while the second does not consider this enrichment $\left(\mathrm{SIM}^{C}\right)$. $\mathrm{SIM}^{C}$ outputs were compared to the data from the surrounding waters where DIP concentration remained very low and constant throughout the experiment. Since mesocosms do not include hydrodynamic processes, this is merely an approximation. However, this comparison provided the opportunity to further validate the model under dramatically different nutrient conditions. For the sake of clarity and better readability, the prefixes " $\mathrm{m}$ " and "o" will be used to refer to model and observations, respectively, and a * will be used to signify data measured outside the mesocosms. Vertical homogeneity was observed in the mesocosms during the experiment for most of the biogeochemical and physical characteristics (Berthelot et al., 2015b; Turk-Kubo et al., 2015; Leblanc et al., 2016). We thus used the average of the three sampling depths to plot both model results and observations. Three periods (namely P0, P1 and P2) were distinguished during the experiment based on biogeochemical characteris-
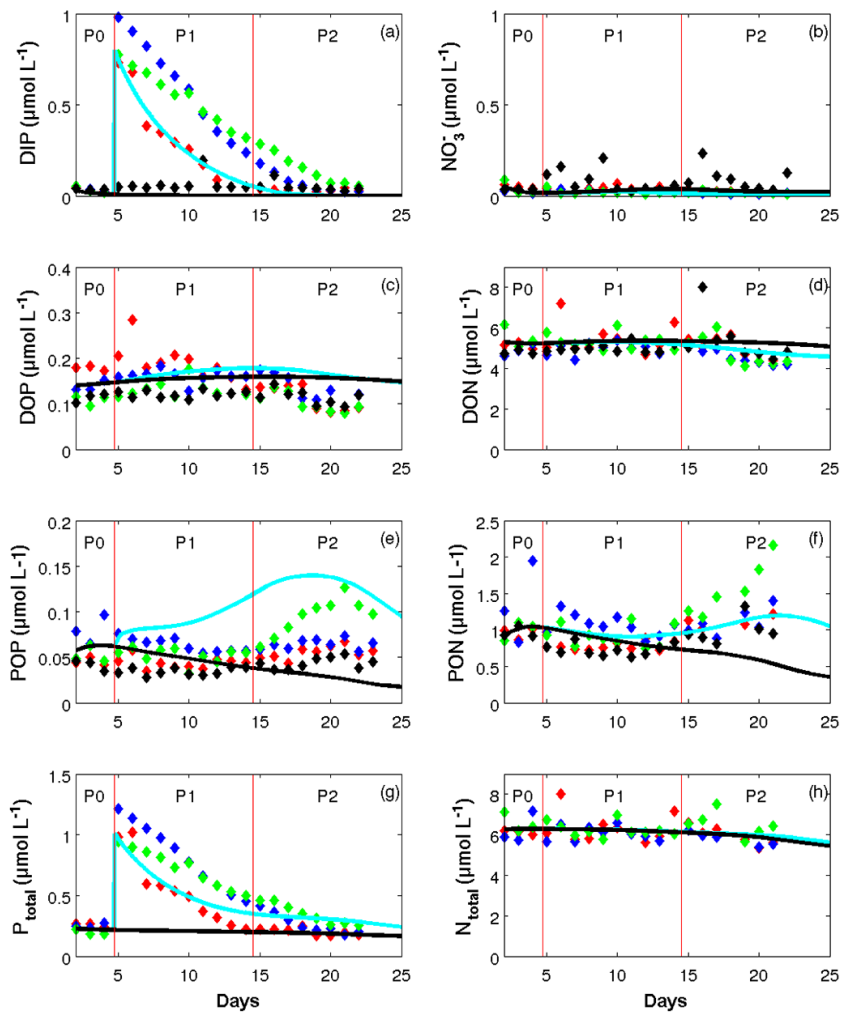

Figure 3. Patterns of change over time in (a) dissolved inorganic phosphate (DIP), (b) nitrate $\left(\mathrm{NO}_{3}^{-}\right)$, (c) dissolved organic phosphate (DOP), (d) dissolved organic nitrogen (DON), (e) particulate organic phosphorus (POP), (f) particulate organic nitrogen (PON), (g) total phosphorus $\left(\mathrm{P}_{\text {total }}\right)$ and $(\mathbf{h})$ total nitrogen $\left(\mathrm{N}_{\text {total }}\right)$ concentrations $\left(\mu \mathrm{mol} \mathrm{L}{ }^{-1}\right)$ in model outputs (solid lines: SIM $^{E}-$ blue; $\mathrm{SIM}^{C}$ - black) averaged over depth superimposed on data observations averaged over depth in the three mesocosms (M1 - red; M2 - blue; M3 - green) and in surrounding waters (black). Red vertical lines distinguish the three periods P0 (before the DIP enrichment), P1 (diatom-diazotroph associations dominate the diazotrophic community) and P2 (unicellular $\mathrm{N}_{2}$-fixing cyanobacteria (Group C) dominate the diazotrophic community).

tics as detailed in Berthelot et al. (2015b) and on changes in the diazotroph community composition (Turk-Kubo et al., 2015). P0 stands for the few days before the DIP enrichment, $\mathrm{P} 1$ is the period when diatom-diazotroph associations dominate the diazotrophic community (i.e., from day 5 to day 14 ), and P2 is the period when UCYN-C dominate the diazotrophic community (i.e., from day 15 to day 23 ).

\subsection{Dynamics of the different $\mathrm{N}$ and $\mathrm{P}$ pools}

During P0, mDIP in $\mathrm{SIM}^{E}$ decreases slowly from 47 to $24 \mathrm{nmol} \mathrm{L}^{-1}$ (Fig. 3a). In response to the DIP enrichment at the end of day 4 , $\mathrm{mDIP}$ reached $830 \mathrm{nmol} \mathrm{L}^{-1}$, before gradually decreasing to the low concentrations observed before the enrichment (Fig. 3a). During the experiment, the DIP enrichment led to three different oDIP in the three mesocosms 
with 740, 780 and $990 \mathrm{nmol} \mathrm{L}^{-1}$ in M1, M2 and M3, respectively, reflecting the slightly different volumes of the mesocosms (Bonnet et al., 2016b). oDIP then decreased below the quantification limit of $50 \mathrm{nmol} \mathrm{L}^{-1}$ in the three mesocosms, but the consumption of oDIP in M1 was the fastest and those in M2 the slowest. Without the DIP enrichment $\left(\mathrm{SIM}^{C}\right), \mathrm{mDIP}$ is quickly consumed and the concentrations remained close to zero until the end of the simulation, consistent with oDIP*, which was $<50 \mathrm{nmol} \mathrm{L}^{-1}$ throughout the experiment. As well as $\mathrm{oNH}_{4}^{+}, \mathrm{mNH}_{4}^{+}$remained low and stable around $15 \mathrm{nmol} \mathrm{L}^{-1}$ throughout the simulation (not shown here). $\mathrm{mNO}_{3}^{-}$also fits in well with $\mathrm{oNO}_{3}^{-}$, with nearly constant concentrations close to the quantification limit of $50 \mathrm{nmol} \mathrm{L}^{-1}$ (Fig. 3b) over the whole simulation.

oDOP and oDON remained relatively stable throughout the experiment, with values around 5 and $0.14 \mu \mathrm{mol} \mathrm{L}^{-1}$, respectively, with a slight decrease in $\mathrm{P} 2$ at the end (Fig. 3c and d). A slight increase in $\mathrm{mDOP}$ in $\mathrm{SIM}^{E}$ from 0.14 to $0.18 \mu \mathrm{mol} \mathrm{L}-1$ and a slight decrease in both $\mathrm{mDOP}$ and mDON were observed during P2. For $\mathrm{SIM}^{C}, \mathrm{mDOP}$ and mDON remained stable throughout the simulated period (Fig. 3c and d).

In the mesocosms, the trend was similar for oPOP (particulate organic phosphorus) and oPON (particulate organic nitrogen), with constant concentrations or a slight decrease during P1, followed by a strong increase during P2 (by a factor of $1.5,1.5$ and 2 in M1, M2 and M3, respectively, in oPON and by a factor of $1.4,1.4$ and 2.4 in M1, M2 and $\mathrm{M} 3$, respectively, in oPOP; Fig. 3e and f). SIM ${ }^{E}$ results are in good agreement with data for $\mathrm{mPON}$, which starts at $1 \mu \mathrm{mol} \mathrm{L}-1$ and then increases to a maximum of $1.5 \mu \mathrm{mol} \mathrm{L}^{-1}$ during P2. While oPOP decreased slightly at the beginning of $\mathrm{P} 1$ and increased during $\mathrm{P} 2$ during the experiment, $\mathrm{mPOP}$ in $\mathrm{SIM}^{E}$ remains constant $\left(0.08 \mu \mathrm{mol} \mathrm{L}{ }^{-1}\right)$ from day 5 to 10 and increases after day 10 . The increase in mPOP up to the $0.14 \mu \mathrm{mol} \mathrm{L}-1$ peak is stronger and occurs earlier than oPOP, before decreasing as in the observed data at the end of P2. In $\operatorname{SIM}^{C}$, the total particulate organic matter dropped throughout the entire simulation, from 0.06 to $0.02 \mu \mathrm{mol} \mathrm{L}^{-1}$ for $\mathrm{mPOP}$ and from 1 to $0.4 \mu \mathrm{mol} \mathrm{L}^{-1}$ for mPON.

In the mesocosms, oN $\mathrm{N}_{\text {total }}$ averaged $6.2 \mu \mathrm{mol} \mathrm{L}^{-1}$ during $\mathrm{P} 1$ and started to decrease at the end of P2 (Fig. 3h). $\mathrm{mN}_{\text {total }}$ in both $\operatorname{SIM}^{E}$ and $\operatorname{SIM}^{C}$ was quite similar and in the same range as that observed in the data, with a slightly sharper decrease for $\mathrm{SIM}^{C}$ at the end of P2. SIM ${ }^{E}$ showed an immediate and strong increase in $\mathrm{mP}_{\text {total }}\left(1-1.2 \mu \mathrm{mol} \mathrm{L}^{-1}\right)$ on day 5 , corresponding to the DIP enrichment, while $\mathrm{mP}_{\text {total }}$ in $\mathrm{SIM}^{C}$ was constant $\left(250 \mathrm{nmol} \mathrm{L}^{-1}\right)$ throughout the simulation (Fig. 3g). After the enrichment, $\mathrm{mP}_{\text {total }}$ started to decline down to $0.2-0.25 \mu \mathrm{mol} \mathrm{L}^{-1}$ on day 22 . In the mesocosms, oChl remained stable during $\mathrm{P} 1$ and increased during $\mathrm{P} 2$ by a factor of 5 up to a maximum of $1 \mu \mathrm{gL}^{-1}$ in M3 (Fig. 4a). oChl $a$ was lower $\left(0.6 \mu \mathrm{g} \mathrm{L}^{-1}\right)$ in M1 and M2 at the end of
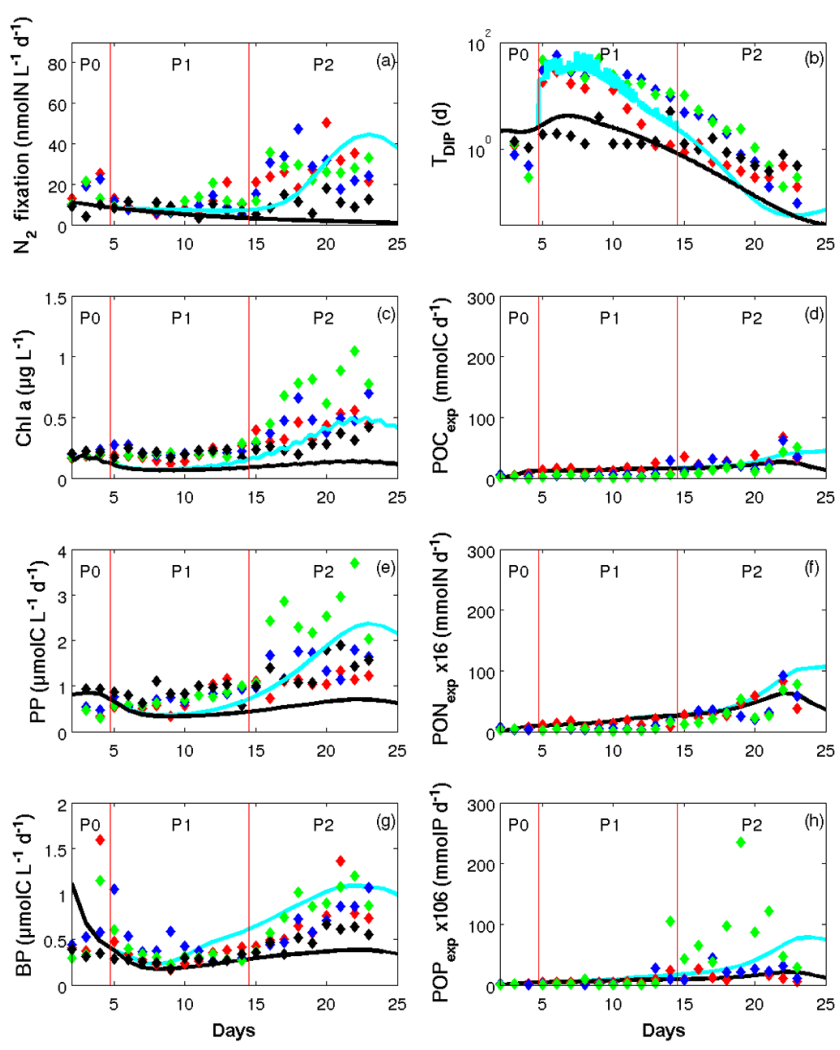

Figure 4. Patterns of change over time in (a) dinitrogen fixation $\left(\mathrm{N}_{2}\right.$ fixation) rates (nmol N L $\left.{ }^{-1} \mathrm{~d}^{-1}\right)$, (b) dissolved inorganic phosphate turnover time ( $T_{\mathrm{DIP}}$, days), (c) chlorophyll $a\left(\mathrm{Chl} a, \mu \mathrm{g} \mathrm{L}^{-1}\right)$, (d) particulate organic $\mathrm{C}$ exported ( $\mathrm{POC}_{\mathrm{exp}}$, dry matter in mmol C), (e) primary production (PP) rates $\left(\mu \mathrm{mol} \mathrm{C} \mathrm{L}{ }^{-1} \mathrm{~d}^{-1}\right)$, (f) particulate organic nitrogen exported $\times 16\left(\mathrm{PON}_{\exp }\right.$, dry matter in mmol $\left.\mathrm{N}\right)$, (g) bacterial production (BP) rates $\left(\mu \mathrm{mol} \mathrm{CL} \mathrm{L}^{-1} \mathrm{~d}^{-1}\right)$ and (h) particulate organic phosphate exported $\times 106\left(\mathrm{POP}_{\exp }\right.$, dry matter in mmol N) in model outputs (solid lines: $\mathrm{SIM}^{E}-$ blue; $\mathrm{SIM}^{C}-$ black) averaged over depth superimposed on data observations averaged over depth in the three mesocosms (M1, red; M2, blue; M3, green) and in surrounding waters (black). Red vertical lines distinguish the three periods P0 (before the DIP enrichment), P1 (diatomdiazotroph associations dominate the diazotrophic community) and P2 (unicellular $\mathrm{N}_{2}$-fixing cyanobacteria (Group C) dominate the diazotrophic community).

P2. mChl $a$ calculated by $\operatorname{SIM}^{E}$ was similar to oChl $a$ in M1 and M2, with a decrease a little more marked during $\mathrm{P} 1$ and a maximum of $0.5 \mu \mathrm{g} \mathrm{L}-1$ in P2. While mChl $a$ increased during $\mathrm{P} 2$ in $\mathrm{SIM}^{E}$, mChl $a$ in $\mathrm{SIM}^{C}$ remained stable $\left(\sim 0.1 \mu \mathrm{g} \mathrm{L}^{-1}\right)$ until the end of the simulation.

\subsection{Dynamics of the different fluxes}

The biogeochemical fluxes relative to the main processes such as primary and bacterial productions (PPs and BPs), $\mathrm{N}_{2}$ fixation ( $\mathrm{N}_{2}^{\mathrm{fix}}$ ), turnover time of DIP ( $\left.T_{\mathrm{DIP}}\right)$, and particulate matter export fluxes (particulate organic $\mathrm{C}\left(\mathrm{POC}_{\exp }\right)$, 
$\mathrm{PON}_{\exp }$ and $\mathrm{POP}_{\exp }$ ) have been calculated by the model and compared to the measured values (Fig. $4 \mathrm{~b}$ to $\mathrm{h}$ ).

At the beginning of $\mathrm{P} 0, \mathrm{oN}_{2}^{\mathrm{fix}}$ as well as $\mathrm{mN}_{2}^{\mathrm{fix}}$ (both in $\operatorname{SIM}^{E}$ and $\operatorname{SIM}^{C}$ ) were about $17 \mathrm{nmolNL}^{-1} \mathrm{~d}^{-1}$ and declined gradually during $\mathrm{P} 1$ down to $10 \mathrm{nmolN} \mathrm{L}^{-1} \mathrm{~d}^{-1}$. While $\mathrm{mN}_{2}^{\mathrm{fix}}$ in $\mathrm{SIM}^{C}$ continued to decrease during $\mathrm{P} 2, \mathrm{mN}_{2}^{\text {fix }}$ in $\mathrm{SIM}^{E}$ increased during $\mathrm{P} 2$ by a factor of 4 , consistent with $\mathrm{oN}_{2}^{\mathrm{fix}}$ and reaching a maximum of $42 \mathrm{nmol} \mathrm{NL}^{-1} \mathrm{~d}^{-1}$ on day 23. Primary and bacterial production (PP and $\mathrm{BP}$ ) exhibited the same temporal dynamics in both data and $\mathrm{SIM}^{E}$ results. They first slightly decreased before the DIP enrichment, remained stable during $\mathrm{P} 1$ and increased during $\mathrm{P} 2$ by a factor of 4.4 and 2.7 for PP and BP, respectively (Fig. 4c and e). During P2, $\mathrm{mPP}\left(\mathrm{SIM}^{E}\right)$ rose to $2 \mu \mathrm{mol} \mathrm{CL} \mathrm{L}^{-1} \mathrm{~d}^{-1}$, which is in the range of the oPP measured in the three mesocosms. M3 exhibited higher values of oPP than those in M1 and M2 during P2 (around $4 \mu \mathrm{mol} \mathrm{CL}^{-1} \mathrm{~d}^{-1}$ on day 22). Even if $\mathrm{mBP}$ (in $\mathrm{SIM}^{E}$ and $\mathrm{SIM}^{C}$ ) started at a higher rate than oBP measured in the three mesocosms, it decreased rapidly from day 2 to 4 to reach the in situ value before the enrichment. The increase in $\mathrm{mBP}$ from day 11 to day 17 in $\mathrm{SIM}^{E}$ was somewhat overestimated compared to data. BP better fitted the data measured at the end of $\mathrm{P} 2$ and especially in $\mathrm{M} 3$ $\left(1 \mu \mathrm{mol} \mathrm{CL} \mathrm{L}^{-1} \mathrm{~d}^{-1}\right)$. In $\mathrm{SIM}^{C}$, the increase in $\mathrm{mBP}$ and $\mathrm{mPP}$ during $\mathrm{P} 2$ did not occur and these rates remained constant around $0.5 \mu \mathrm{mol} \mathrm{C} \mathrm{L}{ }^{-1} \mathrm{~d}^{-1}$ for $\mathrm{mPP}$ and $0.4 \mu \mathrm{mol} \mathrm{C} \mathrm{L} \mathrm{C}^{-1} \mathrm{~d}^{-1}$ for $\mathrm{mBP}$ throughout the 25 days of the simulation. $\mathrm{mBP}$ values in $\mathrm{SIM}^{C}$ were lower than those measured in the three mesocosms and consistent with the oBP values measured in lagoon waters (Fig. 4e).

$T_{\text {DIP }}$ is a relevant indication of DIP availability in the water column. After a slight decline in oT $\mathrm{DIP}_{\text {during }} \mathrm{P} 0$ to values lower than 1 day, $T_{\text {DIP }}$ increased dramatically up to 30 days $\left(\mathrm{o} T_{\mathrm{DIP}}\right)$ and 21 days $\left(\mathrm{mT}_{\mathrm{DIP}}\right)$ after the DIP enrichment. $\mathrm{m} T_{\text {DIP }}$ then decreased linearly in $\mathrm{SIM}^{E}$ as well as o $T_{\mathrm{DIP}}$, in the three mesocosms. $m T_{\mathrm{DIP}}$ in $\mathrm{SIM}^{C}$ showed the same trend as the $\mathrm{oT}_{\text {DIP }}$ measured in the lagoon waters (Fig. 4g).

The fluxes of exported matter $-\mathrm{POC}_{\exp }, \mathrm{PON}_{\exp }$ and $\mathrm{POP}_{\exp }$ for $\mathrm{C}, \mathrm{N}$ and $\mathrm{P}$, respectively - are represented in Fig. $4 \mathrm{~d}, \mathrm{f}$ and $\mathrm{h}$ in terms of dry matter measured in the sediment traps (Berthelot et al., 2015b). During P1, the daily export remained relatively stable and averaged $18,1.13$ and $0.09 \mathrm{mmol}$ for $\mathrm{mPOC}_{\text {exp }}, \mathrm{mPON}_{\text {exp }}$ and $\mathrm{mPOP}_{\text {exp }}$, respectively. $\mathrm{oPOC}_{\text {exp }}, \mathrm{oPON}_{\exp }$ and $\mathrm{oPOP}$ exp gradually increased during P2 (from day 15 to 25 ) to reach a maximum of $57 \mathrm{mmol} \mathrm{Cd}^{-1}, 5 \mathrm{mmol} \mathrm{N} \mathrm{d}^{-1}$ and $0.5 \mathrm{mmol} \mathrm{Pd}^{-1}$, respectively. In $\mathrm{SIM}^{E}$, $\mathrm{mPOC}_{\text {exp }}, \mathrm{mPON}_{\text {exp }}$ and $\mathrm{POP}_{\text {exp }}$ fitted well with data with a slight overestimation of $\mathrm{mPOP}_{\exp }$ at the end of $\mathrm{P} 2$, which reaches a maximum of $0.75 \mathrm{mmol} \mathrm{Pd}^{-1}$. There was no significant difference between $\operatorname{SIM}^{E}$ and $\operatorname{SIM}^{C}$ for $\mathrm{mPOC}_{\text {exp }}$ and $\mathrm{mPON}_{\mathrm{exp}}$, from the beginning of the experiment to the middle of P2 (day 18). From day 19, the increase in $\mathrm{mPOC}_{\text {exp }}$ and $\mathrm{mPON}_{\text {exp }}$ is less important in $\mathrm{SIM}^{C}$ than in $\mathrm{SIM}^{E}$. For $\mathrm{mPOP}_{\text {exp }}$, the increase in $\mathrm{SIM}^{E}$ occurs earlier
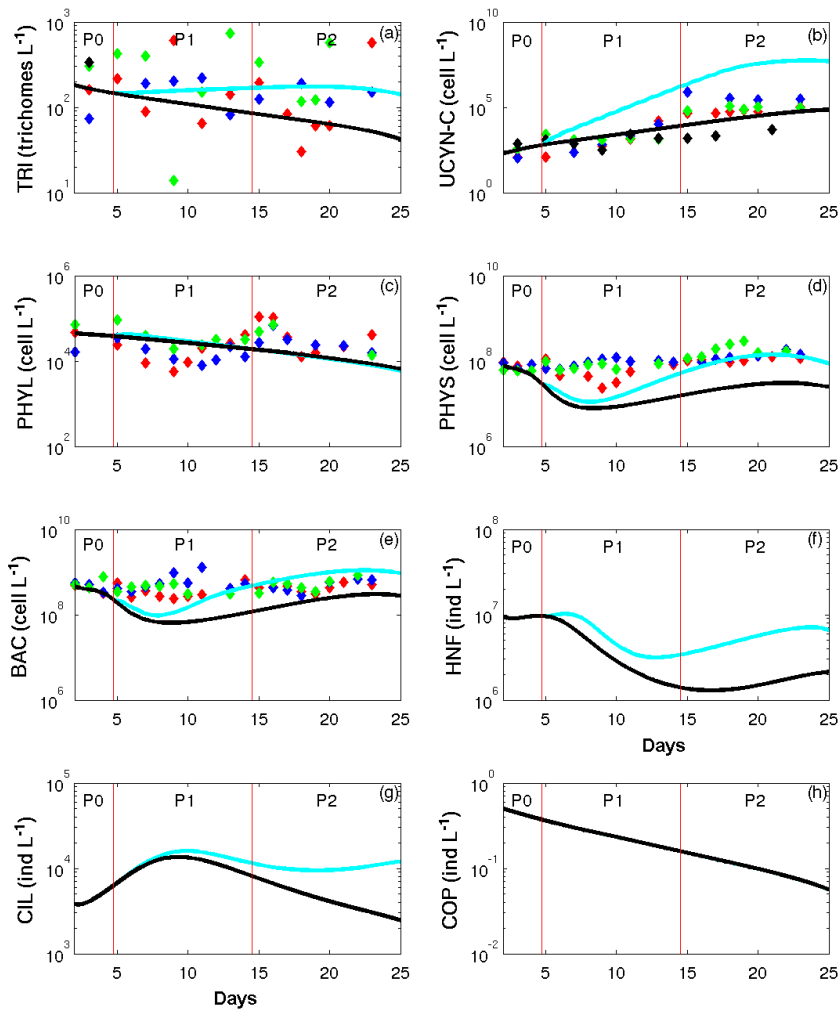

Figure 5. Patterns of change in abundances over time of (a) Trichodesmium (TRI, trichom $\mathrm{L}^{-1}$ ), (b) unicellular $\mathrm{N}_{2}$ fixing cyanobacteria (UCYN-C, cell $\left.\mathrm{L}^{-1}\right)$, (c) large phytoplankton (PHYL, cell $\mathrm{L}^{-1}$ ), (d) small phytoplankton (PHYS, cell $\left.\mathrm{L}^{-1}\right)$, (e) heterotrophic bacteria (BAC, cell $\left.\mathrm{L}^{-1}\right)$, (f) heteronanoflagellates $\left(\mathrm{HNF}\right.$, ind $\left.\mathrm{L}^{-1}\right)$, ciliates $\left(\mathrm{CIL}\right.$, ind $\left.\mathrm{L}^{-1}\right)$ and copepods $\left(\mathrm{COP}\right.$, ind $\left.\mathrm{L}^{-1}\right)$ in model outputs (solid lines: $\mathrm{SIM}^{E}-$ blue; SIM $^{C}$ - black) averaged over depth superimposed on data observations averaged over depth in the three mesocosms (M1 - red; M2 - blue; M3 - green) and in surrounding waters (black). Red vertical lines distinguish the three periods P0 (before the DIP enrichment), P1 (diatom-diazotroph associations dominate the diazotrophic community) and P2 (unicellular $\mathrm{N}_{2}$-fixing cyanobacteria (Group C) dominate the diazotrophic community).

(day 15) and the discrepancy between $\operatorname{SIM}^{E}$ and $\operatorname{SIM}^{C}$ was wider at the end of the simulation.

\subsection{Evolution of planktonic abundances}

The model also simulated the abundances of organisms in cell $\mathrm{L}^{-1}$ for single cells, in trichome $\mathrm{L}^{-1}$ for TRI and in ind $\mathrm{L}^{-1}$ for zooplankton, besides being represented in terms of biomass (C, $\mathrm{N}$ and $\mathrm{P}$ and $\mathrm{Chl}$ for phytoplankton).

mTRI remained constant in $\operatorname{SIM}^{E}$ around 250 trichomes $\mathrm{L}^{-1}$. By contrast, a strong development of UCYN-C occurred during P2, with mUCYN-C reaching $5.10^{7}$ cell $\mathrm{L}^{-1}$ (Fig. 5a and b). This increase in mUCYN-C is consistent with the observed dynamics, though the mUCYN-C increase is overestimated in $\mathrm{SIM}^{E}$ compared 
to oUCYN-C. mPHYL decreased over time in both $\mathrm{SIM}^{E}$ and $\operatorname{SIM}^{C}$ (Fig. 5c). In the three mesocosms, oPHYL increased from day 10 to 15 reaching $10^{5}$ cell L $^{-1}$ before decreasing back to values close to that of mPHYL. During P0, mPHYS decreased slightly like oPHYS. During P1, the decrease in mPHYS (down to $0.1 \times 10^{8}$ cell $\mathrm{L}^{-1}$ ) was stronger than that of oPHYS, which increased from day 10 and reached the same range of values as oPHYS at the beginning of P2. During P2, mPHYS and oPHYS increased up to $1.5 \times 10^{8}$ cell $\mathrm{L}^{-1}$ for mPHYS in $\mathrm{SIM}^{E}$ and $1.3-2.9 \times 10^{8}$ cell $\mathrm{L}^{-1}$ for oPHYS. While mPHYS was similar in $\mathrm{SIM}^{E}$ and $\mathrm{SIM}^{C}$ from day 2 to day 8 , the increase in mPHYS after day 8 and until the end of P2 was lower in $\operatorname{SIM}^{C}$ than in $\operatorname{SIM}^{E}$ (Fig. 5d). As for PHYS, there was a slight decrease in mBAC and oBAC during P0. The DIP enrichment on day 4 led to a strong decline from day 5 to day 8 , which was more marked in $\mathrm{mBAC}\left(9.5 \times 10^{7}\right.$ cell $\mathrm{L}^{-1}$ in $\left.\operatorname{SIM}^{E}\right)$ than in oBAC $\left(2.3-3.1 \times 10^{8}\right.$ cell L $\left.^{-1}\right)$. From day 8 to the end of the simulation, mBAC increased up to a maximum of $1.1 \times 10^{9} \mathrm{cell}^{-1}$, while oBAC reached a maximum of $6.8-8.5 \times 10^{8}$ cell L $^{-1}$ at the end of the experiment. In the same way, $\mathrm{mBAC}$ was similar in $\mathrm{SIM}^{E}$ and $\operatorname{SIM}^{C}$ from day 2 to day 8 and then increased until the end of the simulation but to a lesser extent in $\operatorname{SIM}^{C}$ than in $\operatorname{SIM}^{E}$. Since no zooplankton data that could be used for comparison with the model results were available, only the dynamics of $\mathrm{SIM}^{E}$ and $\mathrm{SIM}^{C}$ are presented (Fig. $5 \mathrm{~g}$ to f). $\mathrm{mHNF}$ and $\mathrm{mCIL}$ showed the same trends though they are time-shifted. mCOP was similar in $\operatorname{SIM}^{E}$ and $\operatorname{SIM}^{C}$, with a decline from 0.5 ind $\mathrm{L}^{-1}$ at the beginning to less than 0.1 ind $\mathrm{L}^{-1}$ at the end of the simulation. Except for mCOP and $\mathrm{mPHYL}$, the DIP enrichment had a strong impact on the plankton dynamics as significant differences between the results of $\mathrm{SIM}^{E}$ and $\mathrm{SIM}^{C}$ in mTRI, mUCYN-C, mPHYS, mBAC, mHNF and mCIL are observed. Overall, SIM $^{C}$ presented abundances 3 to 680 times lower than those simulated by $\operatorname{SIM}^{E}$, though the temporal trends were similar between the two simulations.

\subsection{DIP enrichment and diazotrophs growth}

The model also gives additional information not provided by the data regarding the growth of the organisms or their intracellular content. The population growth rate (in cell $\mathrm{L}^{-1} \mathrm{~s}^{-1}$ ) for TRI and UCYN-C, as well as the specific (i.e., per cell) growth rates (in $\mathrm{s}^{-1}$ ) of TRI and UCYN-C are plotted in Fig. 6a and $\mathrm{b}$, while the relative intracellular $\mathrm{C}, \mathrm{N}$ and $\mathrm{P}$ quotas (i.e., $Q_{\mathrm{C}}, Q_{\mathrm{N}}$ and $Q_{\mathrm{P}}$ ) are plotted in Fig. $6 \mathrm{c}$ and d. The DIP enrichment at the end of day 4 had a direct impact on $Q_{\mathrm{P}}$ for both TRI and UCYN-C, with an instantaneous increase in $Q_{\mathrm{P}}$ up to $100 \%$ on day 5 . While $Q_{\mathrm{C}}, Q_{\mathrm{N}}$ and $Q_{\mathrm{P}}$ for TRI remained at their maximum value until the end, $Q_{\mathrm{N}}$ and $Q_{\mathrm{C}}$ of UCYN-C decreased as soon as $Q_{\mathrm{P}}$ increased on day 5. During P2, $Q_{\mathrm{P}}$ gradually declined for TRI and faster for UCYN-C. The reverse process then occurred with an in-
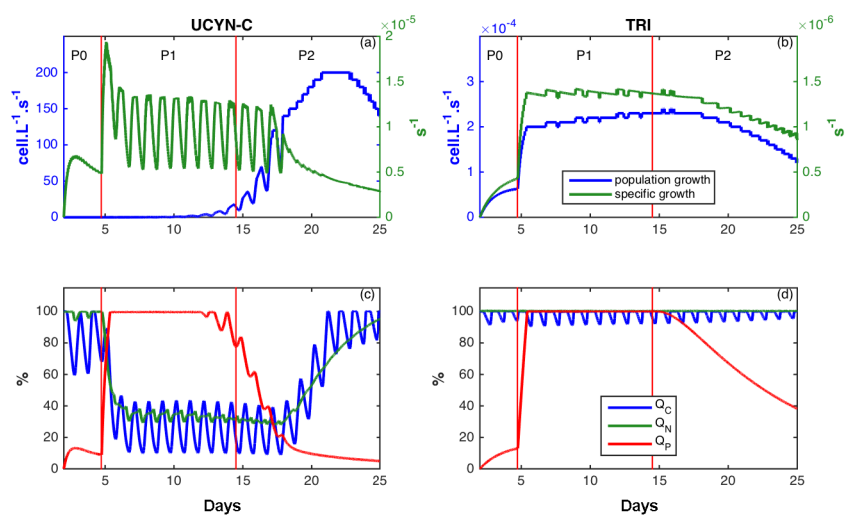

Figure 6. Patterns of change over time in specific (green) and population (blue) growth rates function of (a) unicellular $\mathrm{N}_{2-}$ fixing cyanobacteria (UCYN-C, cell $\mathrm{s}^{-1}$ ) and (b) Trichodesmium (TRI, trichome $\mathrm{s}^{-1}$ ) and carbon $(\mathrm{C}$, blue), nitrogen ( $\mathrm{N}$, green) and phosphorus $(\mathrm{P}$, red) relative intracellular quota in (c) unicellular $\mathrm{N}_{2}$-fixing cyanobacteria (Group C; UCYN-C, \%) and (d) Trichodesmium (TRI, \%) in model outputs in $\mathrm{SIM}^{E}$. Red vertical lines distinguish the three periods P0 (before the DIP enrichment), P1 (diatom-diazotroph associations dominate the diazotrophic community) and P2 (unicellular $\mathrm{N}_{2}$-fixing cyanobacteria (Group C) dominate the diazotrophic community).

crease in $Q_{\mathrm{N}}$ and $Q_{\mathrm{C}}$ for UCYN-C when $Q_{\mathrm{P}}$ decreased from day 15 , whereas this was not observed for TRI. Throughout the simulation, the trends of both population and specific growth rates for TRI were similar, with a sudden increase on day 5 followed by rather constant and then decreasing values (Fig. 6b). By contrast, the increase in the specific growth rate of UCYN-C after the DIP enrichment (day 5) was not observed in the UCYN-C population growth rate, namely on the population scale (Fig. 6a). The population growth rate of UCYN-C increased 10 days later, i.e., during P2, up to a maximum of 200 cell $\mathrm{L}^{-1} \mathrm{~s}^{-1}$ on day 22 .

\subsection{Fate of DDN in the ecosystem}

The fate of the $\mathrm{N}$ that was fixed at the beginning of the simulation (DDN) was examined using the post-processing treatment described in the "Methods" section. In short, the proportion of the total DDN present in each living and non-living compartment of the water column and in the traps was calculated throughout the simulation period (Fig. 7). At the start of the experiment, DDN was nearly exclusively in TRI (the proportion of DDN in UCYN-C was negligible), but this proportion decreased throughout the simulation. Until day 10 , most of the DDN was transferred to the DON pool, which contained about $35 \%$ of the total DDN on day 10 , followed by, in their order of importance, $\mathrm{NH}_{4}^{+}$(up to $10 \%$ on day $5)$, DET ( $12 \%$ on day 10$)$ and the components of the microbial loop. Until day 10, the proportion of DDN in each compartment except TRI, either increased with time or reached a maximum around day 5 , consistent with the decrease in $\mathrm{N}_{2}$ 

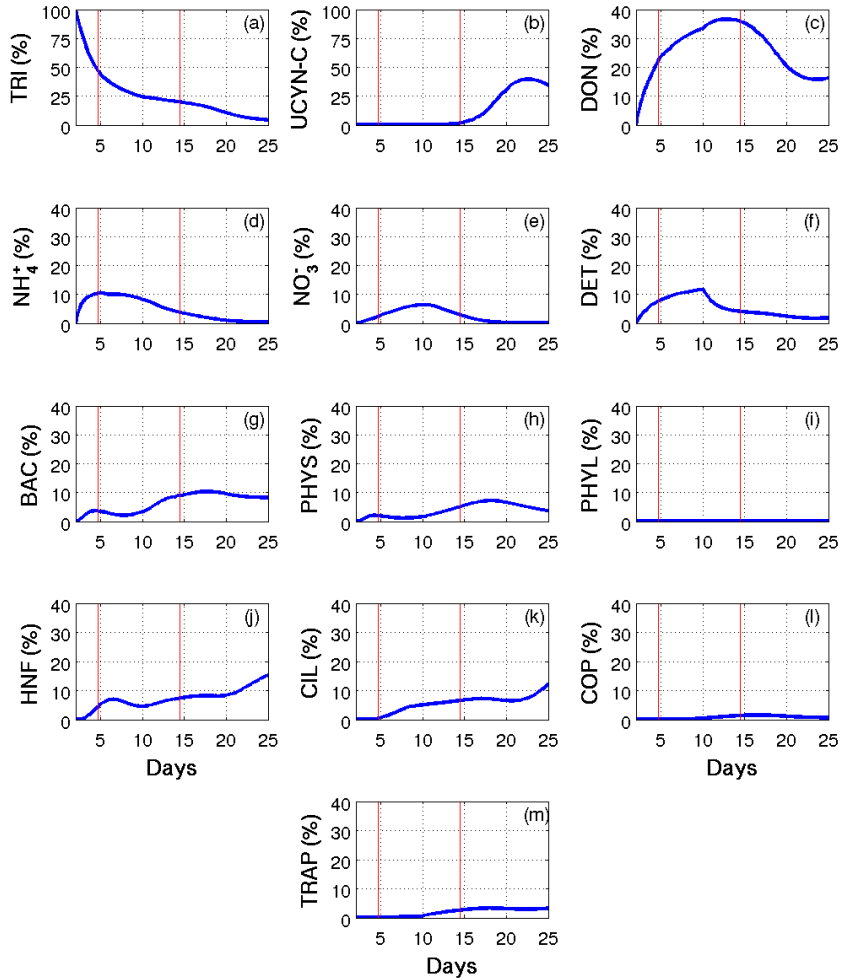

Figure 7. Patterns of change over time of DDN proportion (\%) in (a) Trichodesmium (TRI), (b) unicellular $\mathrm{N}_{2}$-fixing cyanobacteria (Group C) (UCYN-C), (c) dissolved organic nitrogen (DON), (d) ammonium $\left(\mathrm{NH}_{4}^{+}\right)$, (e) nitrate $\left(\mathrm{NO}_{3}^{-}\right)$, (f) detrital nitrogen $\left(\mathrm{DET}_{\mathrm{N}}\right),(\mathrm{g})$ heterotrophic bacteria $(\mathrm{BAC})$, (h) small phytoplankton (PHYS), (i) large phytoplankton (PHYL), (j) hetero-nanoflagellates (HNF), (k) ciliates (CIL), (l) copepods (COP) and (m) in traps (TRAP) in $\mathrm{SIM}^{E}$. Red vertical lines distinguish the three periods P0 (before the DIP enrichment), P1 (diatom-diazotroph associations dominate the diazotrophic community) and P2 (unicellular $\mathrm{N}_{2}$-fixing cyanobacteria (Group C) dominate the diazotrophic community).

fixation rates during that period. After day 10, the proportion of DDN increased in all living organisms, thereby indicating the transfer of DDN to non-diazotrophic organisms. The proportion of DDN increased almost until the end of the simulation in CIL and HNF but only until day 18 in BAC, PHYS and COP before decreasing again. In the non-living compartments, the proportion of DDN decreased after day 10 (day 12 for DON) until the end of the simulation. Finally, the proportion of DDN in traps was almost zero during the first 10 days of the experiment, before increasing and then stabilizing around $4 \%$. The percentage of DDN with respect to total particulate $\mathrm{N}$ contained in the traps was also plotted (Fig. 8). This percentage increased quite linearly with time from 0 to nearly $0.4 \%$ between day 2 and day 10 . On day 10 , the percentage increased much more rapidly until day 12 and then rose gradually to a plateau around $1.2 \%$ before increasing again at the very end of the experiment.

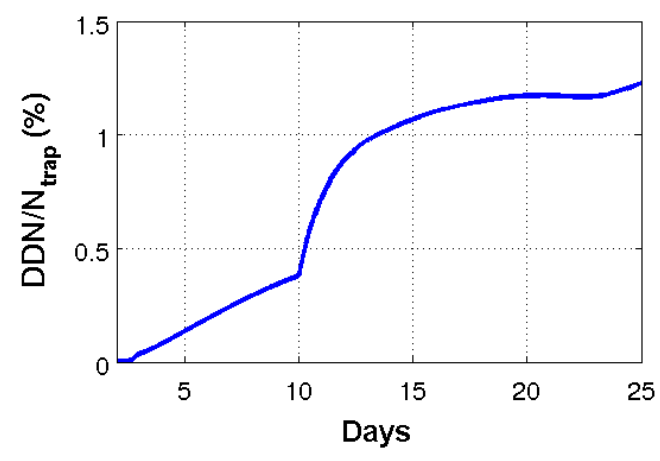

Figure 8. Patterns of change over time of the nitrogen fixation contribution (\%) to particulate matter export in $\operatorname{SIM}^{E}$.

\section{Discussion}

Nitrogen ( $\mathrm{N}$ ) input by $\mathrm{N}_{2}$ fixation in the upper SW Pacific Ocean is thought to be controlled by dissolved inorganic phosphate (DIP) availability because of the presence of repleted trace metals concentrations compared to the adjacent South Pacific central gyre (Moutin et al., 2005, 2008). The aim of the VAHINE experiment (Bonnet et al., 2016b) was to (i) investigate the fate of the diazotroph-derived nitrogen (DDN) in oligotrophic ecosystems by removing any potential DIP limitation for diazotrophs and thereby potentially stimulate the growth of organisms (in particular diazotrophs), (ii) enhance $\mathrm{N}_{2}$ fixation and DDN fluxes through the entire ecosystem, and (iii) study the dynamics of biogeochemical C, $\mathrm{N}$ and $\mathrm{P}$ fluxes. $\mathrm{N}_{2}$ fixation is expected to rapidly deliver new $\mathrm{N}$ to other organisms than diazotrophs, thus reducing possible $\mathrm{N}$ growth limitation or co-limitation in the ecosystem. Our goal was to monitor the dynamics of this new $\mathrm{N}$ toward the food chain, the inorganic and organic $\mathrm{N}$ pools, as well as in the exported particulate matter. The discussion will focus on expected and unexpected results obtained in this study after the DIP enrichment, as well as the fate of DDN in the ecosystem.

\subsection{An expected enhancement of biogeochemical fluxes after the DIP enrichment}

The mesocosms DIP enrichment performed at the end of day 4 associated with the provision of new $\mathrm{N}$ by diazotrophy led to a strong increase in diazotrophs (especially UCYN-C) abundances (Fig. 5a and b), biomass (data not shown) and $\mathrm{N}_{2}$ fixation fluxes during $\mathrm{P} 2$, and a significant development of UCYN-C occurred during that period. Whereas a strong increase in $\mathrm{N}_{2}$ fixation was observed in $\mathrm{SIM}^{E}$ during P2 (consistent with the data indicating a near 3-fold higher mean $\mathrm{N}_{2}$ fixation rate in $\mathrm{P} 2$ than P1; Fig. 4a), $\mathrm{N}_{2}$ fixation rates gradually decreased in $\mathrm{SIM}^{C}$, indicating strong differences between the mesocosm conditions and those encountered in lagoon waters. During the experiment, hydrological parameters such as temperature and biogeochemical conditions were 
all similar inside and outside the mesocosms, except the DIP conditions (Bonnet et al., 2016b), confirming that the DIP enrichment stimulated $\mathrm{N}_{2}$ fixation in the mesocosms. Nevertheless, a slight increase in $\mathrm{N}_{2}$ fixation rates was observed outside the mesocosms during P2 $(+35 \%)$, which could be explained by a provision of external DIP sources to the lagoon, by growth on DOP sources (Dyhrman et al., 2006) and/or by the increasing seawater temperature over the 25-day experiment as mentioned in Bonnet et al. (2016b), which provided favorable conditions for diazotroph growth (Carpenter et al., 2004). A rapid decrease in $T_{\text {DIP }}$ was observed on day 5 after the DIP enrichment, suggesting a rapid consumption of the DIP by the planktonic community both in observed data and in the model outputs. Diazotrophs were the first to respond to the DIP enrichment in term of abundance, even if this response did not lead to an immediate increase in the $\mathrm{N}_{2}$ fixation rate. The latter significantly increased during $\mathrm{P} 2$ in relation to the development of UCYN-C (Turk-Kubo et al., 2015). In the model results, other autotrophic organisms and heterotrophic bacteria declined until the middle of P1 and started to grow 5-10 days after the DIP enrichment (except PHYL). Despite this time lag between the DIP enrichment and the planktonic response, the DIP enrichment resulted in an increase in the abundances of all planktonic groups in the model outputs except PHYL and COP (Fig. 5). The DIP limitation at the beginning of the experiment was represented in the model by setting the $\mathrm{P}$ cell contents of all organisms at their minimum value, which led to an immediate uptake of DIP after the enrichment at the end of day 4 (Fig. 7c and d). On the cellular scale, this immediate DIP uptake resulted in a rapid increase in intracellular $\mathrm{P}$ contents of autotrophs and heterotrophic bacteria up to their maximum quota (Fig. 7c and $\mathrm{d}$ for diazotrophs). After $\mathrm{N}_{2}$ fixation by diazotrophs, the DDN inputs were of benefit to non-diazotrophic organisms. Autotrophic PP and heterotrophic BP increased in the model after the DIP enrichment $(+262$ and $+181 \%$, from day 5 to day 23 for PP and BP, respectively). The enhanced PP (Fig. 5e) led to an increase in total suspended matter (Fig. 3e and f) and finally in exported particulate material (Fig. 4d, f and h). The contribution of $\mathrm{N}_{2}$ fixation to PP (up to $10.0 \%$ for $\operatorname{SIM}^{E}$ and $6.0 \%$ for $\operatorname{SIM}^{C}$ ) is in good agreement with corresponding measured contributions, which were equal to $10.9 \pm 5.0 \%$ inside the mesocosms and $5.7 \pm 2.0 \%$ in the lagoon waters (Berthelot et al., 2015b). Hence, the DIP enrichment not only stimulated $\mathrm{N}_{2}$ fixation and PP but also the percentage of PP sustained by $\mathrm{N}_{2}$ fixation. The newly synthesized biomass had two possible fates, namely remineralization or export.

Throughout the experiment, Turk-Kubo et al. (2015) has shown that DDAs were the most abundant diazotrophs in the mesocosms during P1. However, it has been shown by Berthelot et al. (2015b) that they did not represent a significant biomass, and the associated export flux was low compared to the export flux measured during P2. Moreover, due to their rapid settling (Villareal et al., 1996), DDN produced by DDAs were not of benefit to the system. For these reasons, we decided not to include DDAs in the model.

During P1, the export in $\mathrm{SIM}^{E}$ is unexpectedly in good agreement with data, probably due to the overestimation of UCYN-C by the model (Fig. 5b). The export during P1 was however lower than during P2, during which we observed a higher increase in suspended particulate matter (Fig. 4d, f and $h$ ) enhanced by the more significant UCYN-C growth, not clearly noticeable with the logarithmic scale in Fig. $5 \mathrm{~b}$. Moreover, the presence of large $(100-500 \mu \mathrm{m}) \mathrm{UCYN}-\mathrm{C}$ aggregates in the mesocosms facilitated their export into the traps where UCYN-C accounted for up to $22.4 \pm 4.0 \%$ of total $\mathrm{C}$ export at the height of their extensive development (Bonnet et al., 2016a). This indicates that UCYN-C cannot only contribute to direct export but promote indirect export. The high content of TEP measured in traps by Berman-Frank et al. (2016) on days 15 and 16 in correlation with the increase in UCYN-C abundances observed by Turk-Kubo et al. (2015) led to the assumption that the presence of TEP in the field would facilitate export flux and especially the sinking of UCYN-C during P2. This phenomenon was taken into account in the model by allowing, each day from day 10 , the settling of $10 \%$ of all the model compartments (living and non-living, particulate and dissolved) in addition to the detrital particulate matter. $\mathrm{C}, \mathrm{N}$ and $\mathrm{P}$ export in $\mathrm{SIM}^{E}$ closely follows the mesocosm trap measurements (Fig. 6d, $f$ and $h$ ). $\mathrm{SIM}^{E}$ shows higher $\mathrm{C}, \mathrm{N}$ and $\mathrm{P}$ exports $(+28,+35$ and $+158 \%$, respectively) compared to $\mathrm{SIM}^{C}$. Large-size $\mathrm{N}_{2}-$ fixing organisms are known to directly contribute to $\mathrm{C}$ export in coastal and oceanic environments (Subramaniam et al., 2008; Karl and Letelier, 2008), but small-size UCYN-C, although very few studies have focused on them, were considered less efficient at promoting export due to their small size (typically $1-6 \mu \mathrm{m}$ ) associated with low individual sinking rates and the tight grazing control that leads to high recycling rates in the euphotic zone. In the present study, both our experimental and model results indicated that UCYN-C also significantly contributed to export under DIP repleted conditions, both directly by the sinking of UCYN-C cells and indirectly after the transfer of DDN to non-diazotrophic plankton, which was subsequently exported.

\subsection{An unexpected delay for UCYN-C development and biogeochemical fluxes enhancement}

The new $\mathrm{N}$ provided by $\mathrm{N}_{2}$ fixation after the DIP enrichment resulted in high PP and BP rates, as well as in an increase in export and planktonic abundances. However, these responses were not observed immediately after the DIP enrichment on day 4 but 5-10 days later (Figs. 3 and 5). The massive UCYN-C development occurred during P2, with a maximum population growth on day 21 in the model, consistent with the observation of the maximum in the UCYN-C abundances reported in Turk-Kubo et al. (2015), on days 20, 15 and 19 in M1, M2 and M3, respectively (Fig. 5b). 


\subsubsection{What factor may explain the 5-10-day delay between the DIP enrichment and the large UCYN-C development?}

On the cellular scale (Fig. 6a), the DIP enrichment had an immediate influence on cell-specific growth rate of UCYN$\mathrm{C}$, with a 4-fold increase in a few hours. However, this immediate response was not observed on the population scale (Fig. 6a). At the beginning of the simulation, the $\mathrm{P}$ cell quota of UCYN-C was at a minimum, and UCYN-C cellspecific growth rate was therefore equal to zero. Though DIP and DOP were very low at the beginning of the simulation, UCYN-C could however take up part of this available $\mathrm{P}$, thereby increasing their $\mathrm{P}$ quota and their growth rate. UCYN-C reached their maximum cellular P quota the day after the DIP enrichment (Fig. 6c) and DIP did not further limit the UCYN-C growth until day 17. The peak in cellspecific growth rate at day 5 (Fig. 6c) corresponds to the temporary absence of significant nutrient limitation, while oscillations during the following days correspond to the daynight rhythm in UCYN-C C quota associated with C starvation during the night (the specific growth rate is modulated by the lowest intracellular quota). When $\mathrm{C}$ is the most limiting nutrient, the night-day oscillations are passed on to the growth rate. The strong increase in the cell-specific growth rate on day 5 led to an increase in UCYN-C abundances (Fig. 5b). After day 5, photosynthesis and $\mathrm{N}$ uptake were then not rapid enough to sustain the increased $\mathrm{C}$ and $\mathrm{N}$ needs, and $\mathrm{N}$, and mostly $\mathrm{C}$ at night, became limiting (Fig. 6c). As a consequence, UCYN-C cell-specific growth rate decreased slightly after day 5 and more rapidly after day 18 when DIP once again became limiting (Fig. 6a). Figure 6 illustrates the time lag between the variations at the cellular level for specific growth rate and growth at the population level. The growth rate of the UCYN-C population also increased from the beginning of the simulation since the specific growth rate and the abundance of UCYN-C increased, but this was almost imperceptible until the exponential increase started around day 11. From day 18, when the specific growth rate began to strongly decrease, the population growth rate still increased but more slowly and finally decreased after the maximum of $5.10^{7}$ cell L $\mathrm{L}^{-1} \mathrm{~s}^{-1}$ reached on day 22 (Fig. 6a). TRI abundance was less influenced by the DIP enrichment than UCYN-C abundance. However, the DIP enrichment led to an increase in TRI growth rate on day 5 on both the population and trichome scale (Fig. 6c). Since a trichome includes 100 cells of Trichodesmium, the time lag between the responses at the trichome and population levels was therefore far less than that evidenced for UCYN-C. Furthermore, although TRI growth was not nutrient-limited from day 5 to day 15 as the three cellular quotas (C, N and P) were at their maximum value (Fig. 6d), the TRI population did not increase significantly because of its low maximum division rate as compared to the timescale of the experiment (3 weeks; consistent with in situ data).

\subsubsection{Discussion on the time duration of enrichment experiments}

The aforementioned time lag between cellular and population responses is also useful for understanding what may be viewed as a contradiction: on one hand, we observed a clear and net increase in PP, BP and export productions after the DIP enrichment, both in the mesocosms and in the $\mathrm{SIM}^{E}$, but on the other hand, oligotrophic waters are generally known to be more DIN- than DIP-limited. After reviewing the main studies conducted on nutrient limitation, and especially on $\mathrm{N}$ and P limitation in oligotrophic waters, Moore et al. (2013) concluded that $\mathrm{N}$ was the first limiting nutrient for phytoplankton in nutrient-depleted areas as nutrient-addition experiments did not lead to a significant increase in autotrophic activity after $\mathrm{P}$ additions, whereas it did after $\mathrm{N}$ additions (Thingstad et al., 2005; Moore et al., 2008; Tanaka et al., 2011; Zohary et al., 2005). Similar results were obtained in the South Pacific gyre for autotrophs (Bonnet et al., 2008) and heterotrophs (Van Wambeke et al., 2008). Van Wambeke et al. (2016) also observed a proximal $\mathrm{N}$ limitation of BP at the beginning of the present mesocosm experiment (before the DIP enrichment) on short timescales (days). This apparent contradiction regarding DIP limitation may therefore be explained by the time duration of the aforementioned DIP enrichment experiments that was not long enough to evidence the response of the planktonic ecosystem. The enrichment mesocosm experiment conducted during the VAHINE project made it possible to monitor the ecosystem and the associated biogeochemical fluxes over a longer period of time (23 days) compared to the nutrient-addition experiments cited above. Since we observed a significant increase in PP and BP about 5-10 days after the DIP enrichment in both experimental (M2 and M3, 5 days for M1) and simulation results, we may conclude that around 5-10 days are necessary for the newly fixed $\mathrm{N}$ by diazotrophs to sustain the observed high production rates and to see an effective change in the planktonic populations (in term of abundances, structure and function). In the light of the foregoing, two conclusions may therefore be drawn. First, 5 days may be the lowest time limit to characterize the real nutrient-limiting primary, bacterial and export productions, at least in marine areas where $\mathrm{N}_{2}$ fixation is a significant process. Therefore, short-term ( $\sim 2$ days) nutrient-addition experiments may not be wellsuited to studying nutrient limitation in marine ecosystems. Second, the initial DIP limitation considered in the model clearly indicates that DIP limitation observed at the cellular level does not reflect the response on the population scale (in terms of primary, bacterial and export productions), which may be delayed. Therefore, in order to correctly assess the nutrient limitation during short-term nutrient-addition experiments, nutrient limitation diagnostics operating at a cellular level (such as enzymatic responses) need to be applied rather than classical measurements of PP or BP increase after the enrichment. 


\subsection{The fate of DDN in the planktonic ecosystem and exported matter}

At the start of the simulation, DDN was almost exclusively in TRI since the flux of $\mathrm{N}_{2}$ fixation by UCYN-C was negligible compared to that of TRI, and the situation was reversed at the end of the simulation when UCYN-C abundance became predominant. Due to DON exudation and $\mathrm{NH}_{4}^{+}$release by TRI, the proportion of DDN first increased in the DON and $\mathrm{NH}_{4}^{+}$pools and then in the $\mathrm{NO}_{3}^{-}$pool due to nitrification. Before day 10, planktonic organisms did not significantly benefit from the DDN, as its proportion decreased in BAC and PHYS between days 4 and 8 and in HNF between days 6 and 10. For BAC and PHYS, this was mainly due to the decrease (which is overestimated by the model) in abundance of these two groups between days 5 and 8 due to grazing by HNF and CIL. After day 10, the DDN proportion increased in all the non-diazotrophic plankton groups, while it decreased in the non-living pools, though somewhat later (i.e., from day 13) in DON. This decrease in DDN proportion in the non-living pools is both due to the assimilation of mineral and organic nutrients by phyto- and bacterioplankton and to the sinking of the produced organic matter through aggregation processes. Since mineral N is first taken up, the uptake of DON occurs later, namely during $\mathrm{P} 2$, as shown in Berthelot et al. (2015b). As a consequence, the decrease in DDN-DON percentage was also delayed as compared to that of $\mathrm{NO}_{3}^{-}$and $\mathrm{NH}_{4}^{+}$. DDN-DET increased quite regularly until day 10 as long as the sinking rate was constant and then decreased with the increase in this sinking rate. As a result, DDN in the particulate matter collected in traps increased from day 10 to the end, consistent with the $\delta_{15}$ budget performed by Knapp et al. (2016), thereby indicating a higher contribution of $\mathrm{N}_{2}$ fixation to export production during P2 ( $56 \pm 24 \%$ and up to $80 \%$ at the end of the experiment) compared to P1 ( $47 \pm 6$ and up to $60 \%$ ). $\mathrm{mDON}$ appeared to be the pool which mainly benefitted from the DDN. This is due to the DON release by diazotrophs, especially TRI, which was at its maximum $\mathrm{N}$ quota throughout the simulation (Fig. 8c and d). Since the TRI maximum cell division rate was low, their $\mathrm{N}_{2}$ fixation rate is indeed high enough to allow Trichodesmium to fulfill their $\mathrm{N}$ reserves and reach their maximum $\mathrm{N}$ quota (Fig. 6d). The same is not true for UCYN-C, for which the division rate (boosted by the $\mathrm{P}$ enrichment) was too high, as compared to their $\mathrm{N}$ fixation rate, to reach their $\mathrm{N}$ maximum quota. However, in the model, DDN exudation by diazotrophs released equal amounts of $\mathrm{NH}_{4}^{+}$and DON. During P1, DDN accumulated in DON (up to almost $40 \%$ on day 13; Fig. 7c), whereas DDN in $\mathrm{NH}_{4}^{+}$ decreased rapidly from day 5 as it was immediately used by heterotrophic bacteria and phytoplankton (Fig. 7d). DDN in DON decreased later (i.e., during P2, when the DON pool began to be used) as the inorganic $\mathrm{N}$ pool was depleted. Finally, though DDN transited in the same proportions in $\mathrm{NH}_{4}^{+}$ and DON, it mostly accumulated in DON since DDN- $\mathrm{NH}_{4}^{+}$ was taken up more rapidly, these results substantiating those found by Berthelot et al. (2015b). Among the living compartments, PHYS, BAC, HNF and CIL were the main beneficiaries of DDN. PHYS and BAC were indeed the main consumers of $\mathrm{NH}_{4}^{+}$and labile DON (while PHYL was not allowed by the model to uptake DON), and HNF and CIL, respectively, feed on BAC and PHYS and on PHYS and HNF. DDN therefore mainly transited through the actors of the microbial loop, which is consistent with nanoSIMS measurements performed after $24 \mathrm{~h}$ of incubation with ${ }^{15} \mathrm{~N}_{2}$ on water sampled on day 17 , showing that $18 \pm 4 \%$ of the DDN was found in picophytoplankton against $3 \pm 2 \%$ in diatoms (Bonnet et al., 2016a). According to the model, only $5 \%$ of the total DDN were recovered in the traps at the end of the simulation. This proportion is likely underestimated by the fact that UCYN-C sinking is probably underestimated in the model. The contribution of UCYN-C to POC export on day 17 during $\mathrm{P} 2$ was indeed $0.25 \%$ in the model simulation, against up to $22.4 \pm 4.0 \%$ in the data during the same period as reported in Bonnet et al. (2016a). In the same way, the ratio DDN / total $\mathrm{N}$ in traps was equal to $1 \%$ at the end of the simulation, which is dramatically lower than the measured value, which is equal to $80 \%$ (Knapp et al., 2016). This discrepancy is partially due to the different methodologies used to make these estimations. In the post-processing treatment, we considered that the initial DDN was zero in every compartment, which is obviously not true, but this hypothesis was constrained by the fact that the initial DDN in all the model compartments was unknown, and arbitrary allocations of DDN in compartments would have added additional uncertainty to the model results. As a consequence, our results are necessarily underestimated as compared to the measured values since the latter include the history of previous $\mathrm{N}_{2}$ fixation in the field (i.e., before the beginning of the mesocosm experiment). If we consider that an initial content of DDN in the traps equals $30 \%$ as measured by Knapp et al. (2016), the final modeled DDN content would be $31 \%$, which is still underestimated but more realistic. This approximation of the initial zero DDN content in organisms is therefore not sufficient to explain the huge difference to observations concerning the DDN proportion in traps. Another source of error lies in the implicit representation of the aggregation process given in this study. It has been considered that from day $10,10 \%$ of all the model variables are allowed to sink in addition to the detrital particulate compartment. However, it seems that this leads to an underestimation of UCYN-C sinking. As already mentioned, Bonnet et al. (2016a) showed that the UCYN-C contribution to the particulate $\mathrm{C}$ collected in traps on day 17 was up to $22.4 \pm 4.0 \%$ as against $0.25 \%$ for the model. The in situ value has been estimated using a value of the intracellular $\mathrm{C}$ content per cell of $22 \mathrm{pgC}$ cell $^{-1}$, determined according to the measured UCYN-C cell size in the mesocosms and the equations of Verity et al. (1992) . However, the modeled C intracellular content of UCYN-C 
at day 17 is about 150 times lower $\left(0.13 \mathrm{pgCcell}^{-1}\right)$. This difference in UCYN-C C contents is due to the straightforward hypothesis we made in the model which was to consider the UCYN-C diazotrophs as PHYS. Our aim was to use the same model developed for the oligotrophic ocean and particularly the Mediterranean Sea (Eco3M-MED) in every oligotrophic region of the ocean. Moreover, we considered that it was potentially informative to consider that the diazotrophs added in the model were similar in all points to PHYS and PHYL except that they were able to fix $\mathrm{N}_{2}$. In the model, PHYS represents picophytoplankton and the small nanophytoplankton, and its $\mathrm{C}$ intracellular content ranged between 0.08 and $0.25 \mathrm{pgC}^{-1} \mathrm{cell}^{-1}$, which seems to be an underestimated value for UCYN-C. During the VAHINE experiment, Bonnet et al. (2016a, b) have shown that large cells of UCYN-C (size about $5.7 \mu \mathrm{m}$ ) were present with a $\mathrm{C}$ content estimated at $22 \mathrm{pgC} \mathrm{cell}^{-1}$. With the latter $\mathrm{C}$ content, we established that the mUCYN-C contribution to export would reach $28 \%$, a result consistent with the $22.4 \pm 4.0 \%$ estimated by Bonnet et al. (2016a). Finally, the overestimation of UCYN-C abundance by the model also supports the idea that UCYN-C sinking is underestimated by the model. The aggregation process induced by TEP (Berman-Frank et al., 2016) or by specific molecules such as extracellular polysaccharides (EPSs; Sohm et al., 2011), which is not explicitly represented in the model, might explain the preferential export of UCYN-C in the mesocosms. Hence, though aggregation was probably overestimated in the mesocosms as compared to natural situations, the contribution of this process seems to be significant in $\mathrm{C}$ export. The overestimation of UCYN-C in the model during P2 might also be explained by an underestimation of the grazing by HNF and CIL. Nevertheless, we did not go further in this assumption since few data regarding grazing rates by zooplankton were available in this study. Overall, despite the clear underestimation by the model of the UCYN-C sinking and DDN export, the main conclusions delivered by the model concerning the fate of DDN through the planktonic food web remain unchanged.

\section{Conclusions}

The DIP enrichment conducted during the VAHINE mesocosms experiment in the oligotrophic water of the New Caledonia lagoon (southwest Pacific Ocean) led to a clear increase in primary, bacterial and export productions. Two simulations, with and without considering the DIP enrichment, were run. Their comparison enabled the quantification of the increase in the main biogeochemical fluxes due to the DIP enrichment. This modeling work was also intended to investigate the fate of the $\mathrm{N}$ provided by $\mathrm{N}_{2}$ fixation (i.e., $\mathrm{DDN}$ ) throughout the planktonic food web. The dynamics of the functional groups provided by the simulation with the DIP enrichment were generally consistent with the measured values, especially the development of UCYN-C 10 days after the DIP enrichment. The time lag of 5-10 days (concomitant with the increase in primary, bacterial and export productions) raises the question of the suitability of the classical methods used to quantify primary and bacterial nutrient limitation, at least in areas where $\mathrm{N}_{2}$ fixation may sustain a large proportion of new PP. This modeling study also enabled us to monitor the fate of the new $\mathrm{N}$ input by $\mathrm{N}_{2}$ fixation (DDN) in the ecosystem. According to the model, DDN is mainly found in the dissolved pool $\left(\mathrm{NH}_{4}^{+}\right.$and $\left.\mathrm{DON}\right)$ before benefiting the whole planktonic community. At the end of the simulation, 43, 33 and $15 \%$ were found in non-diazotroph organisms, UCYN-C and DON, respectively. The exported matter collected in the traps at $15 \mathrm{~m}$ depth showed that export is essentially due to the sinking of small organisms. Although the measured and simulated $\mathrm{C}, \mathrm{N}$ and $\mathrm{P}$ export was consistent in magnitude, the simulated percentage of DDN in traps was significantly lower than that of experimental measurements. During the experiment, UCYN-C export was high, probably due to their aggregation in larger particles because of the secretion of TEP or EPS, which increased their own sinking velocity rather than the sinking velocity of the whole suspended matter as considered in the present model. Directly or indirectly, small diazotrophs significantly contribute to the particulate export through the aggregation process, which needs to be further investigated in future work.

Acknowledgements. Funding for this research was provided by the Agence Nationale de la Recherche (ANR starting grant VAHINE ANR-13-JS06-0002), the INSU-LEFE-CYBER program, GOPS and IRD. The authors would like to thank three anonymous reviewers for their time and criticism, which improved the quality of this manuscript, as well as all the colleagues working on the VAHINE project for providing the data needed for the setup and the validation of the model used in this work.

Edited by: F. Lacan

Reviewed by: three anonymous referees

\section{References}

Alekseenko, E., Raybaud, V., Espinasse, B., Carlotti, F., Queguiner, B., Thouvenin, B., Garreau, P., and Baklouti, M.: Seasonal dynamics and stoichiometry of the planktonic community in the NW Mediterranean Sea; a 3-D modeling approach, Ocean Dynam., 64, 179-207, 2014.

Baklouti, M., Faure, V., Pawlowski, L., and Sciandra, A.: Investigation and sensitivity analysis of a mechanistic phytoplankton model implemented in a new modular numerical tool (Eco3M) dedicated to biogeochemical modelling, Prog. Oceanogr., 71, 34-58, doi:10.1016/j.pocean.2006.05.003, 2006.

Benavides, M., Agawin, N., Aristegui, J., Penne, J., and Stal, L.: Dissolved organic nitrogen and carbon release by a marine unicellular diazotrophic cyanobacterium, Aquat. Microb. Ecol., 69, 69-80, 2013a. 
Benavides, M., Bronk, D. A., Agawin, N. S. R., Pérez-Hernández, M. D., Hernández-Guerra, A., and Arstegui, J.: Longitudinal variability of size-fractionated $\mathrm{N}_{2}$ fixation and DON release rates along $24.5^{\circ} \mathrm{N}$ in the subtropical North Atlantic: $\mathrm{N}_{2}$ Fixation in the North Atlantic, J. Geophys. Res.-Oceans, 118, 3406-3415, doi:10.1002/jgrc.20253, 2013b.

Bergman, B. and Carpenter, E. J.: Nitrogenase confined to randomly distributed trichomes in the marine cyanobacterium Trichodesmium thiebautii, J. Phycol., 27, 158-165, doi:10.1111/j.0022-3646.1991.00158.x, 1991.

Berman-Frank, I., Lundgren, P., Chen, Y.-B., Küpper, H., Kolber, Z., Bergman, B., and Falkowski, P.: Segregation of nitrogen fixation and oxygenic photosynthesis in the marine cyanobacterium Trichodesmium, Science, 294, 1534-1537, 2001.

Berman-Frank, I., Spungin, D., Rahav, E., Van Wambeke, F., TurkKubo, K., and Moutin, T.: Dynamics of transparent exopolymer particles (TEP) during the VAHINE mesocosm experiment in the New Caledonian lagoon, Biogeosciences, 13, 3793-3805, doi:10.5194/bg-13-3793-2016, 2016.

Berthelot, H., Bonnet, S., Camps, M., Grosso, O., and Moutin, T.: Assessment of the dinitrogen released as ammonium and dissolved organic nitrogen by unicellular and filamentous marine diazotrophic cyanobacteria grown in culture, Front. Mar. Sci., 2, 80, doi:10.3389/fmars.2015.00080, 2015a.

Berthelot, H., Moutin, T., L'Helguen, S., Leblanc, K., Hélias, S., Grosso, O., Leblond, N., Charrière, B., and Bonnet, S.: Dinitrogen fixation and dissolved organic nitrogen fueled primary production and particulate export during the VAHINE mesocosm experiment (New Caledonia lagoon), Biogeosciences, 12, 40994112, doi:10.5194/bg-12-4099-2015, 2015b.

Biegala, I. C. and Raimbault, P.: High abundance of diazotrophic picocyanobacteria $(<3 \mu \mathrm{m})$ in a Southwest Pacific coral lagoon, Aquat. Microb. Ecol., 51, 45-53, 2008.

Bonnet, S., Guieu, C., Bruyant, F., Prášil, O., Van Wambeke, F., Raimbault, P., Moutin, T., Grob, C., Gorbunov, M. Y., Zehr, J. P., Masquelier, S. M., Garczarek, L., and Claustre, H.: Nutrient limitation of primary productivity in the Southeast Pacific (BIOSOPE cruise), Biogeosciences, 5, 215-225, doi:10.5194/bg-5-215-2008, 2008.

Bonnet, S., Rodier, M., Turk-Kubo, K. A., Germineaud, C., Menkes, C., Ganachaud, A., Cravatte, S., Raimbault, P., Campbell, E., Quéroué, F., Sarthou, G., Desnues, A., Maes, C., and Eldin, G.: Contrasted geographical distribution of $\mathrm{N}_{2}$ fixation rates and nifH phylotypes in the Coral and Solomon Seas (SouthWestern Pacific) during austral winter conditions, Biogeochem. Cy., 29, 1874-1892, 2015.

Bonnet, S., Berthelot, H., Turk-Kubo, K., Fawcett, S., Rahav, E., L'Helguen, S., and Berman-Frank, I.: Dynamics of $\mathrm{N}_{2}$ fixation and fate of diazotroph-derived nitrogen in a low-nutrient, low-chlorophyll ecosystem: results from the VAHINE mesocosm experiment (New Caledonia), Biogeosciences, 13, 2653-2673, doi:10.5194/bg-13-2653-2016, 2016a.

Bonnet, S., Moutin, T., Rodier, M., Grisoni, J.-M., Louis, F., Folcher, E., Bourgeois, B., Boré, J.-M., and Renaud, A.: Introduction to the project VAHINE: VAriability of vertical and tropHIc transfer of diazotroph derived $\mathrm{N}$ in the south wEst Pacific, Biogeosciences, 13, 2803-2814, doi:10.5194/bg-13-28032016, 2016 b.
Bryceson, I. and Fay, P.: Nitrogen fixation in Oscillatoria (Trichodesmium) erythraea in relation to bundle formation and trichome differentiation, Mar. Biol., 61, 159-166, doi:10.1007/BF00386655, 1981.

Carpenter, E. J. and Price, C. C.: Marine oscillatoria (Trichodesmium): explanation for aerobic nitrogen fixation without heterocysts, Science, 191, 1278-1280, doi:10.1126/science.1257749, 1976.

Carpenter, E. J., Subramaniam, A., and Capone, D. G.: Biomass and primary productivity of the cyanobacterium Trichodesmium spp. in the tropical N Atlantic ocean, Deep-Sea Res. Pt. I, 51, 173203, doi:10.1016/j.dsr.2003.10.006, 2004.

Christaki, U., Van Wambeke, F., Lefevre, D., Lagaria, A., Prieur, L., Pujo-Pay, M., Grattepanche, J.-D., Colombet, J., Psarra, S., Dolan, J. R., Sime-Ngando, T., Conan, P., Weinbauer, M. G., and Moutin, T.: Microbial food webs and metabolic state across oligotrophic waters of the Mediterranean Sea during summer, Biogeosciences, 8, 1839-1852, doi:10.5194/bg-8-1839-2011, 2011.

Dupouy, C., Neveux, J., Subramaniam, A., Mulholland, M. R., Montoya, J. P., Campbell, L., Carpenter, E. J., and Capone, D. G.: Satellite captures Trichodesmium blooms in the southwestern tropical Pacific, EOS, Transactions American Geophysical Union, 81, 13-16, 2000.

Dutkiewicz, S., Ward, B. A., Monteiro, F., and Follows, M. J.: Interconnection of nitrogen fixers and iron in the Pacific Ocean: Theory and numerical simulations, Global Biogeochem. Cy., 26, GB1012, doi:10.1029/2011GB004039, 2012.

Dyhrman, S. T., Chappell, P. D., Haley, S. T., Moffett, J. W., Orchard, E. D., Waterbury, J. B., and Webb, E. A.: Phosphonate utilization by the globally important marine diazotroph Trichodesmium, Nature, 439, 68-71, 2006.

El-Shehawy, R.: Diurnal expression of hetR and diazocyte development in the filamentous non-heterocystous cyanobacterium Trichodesmium erythraeum, Microbiology, 149, 1139-1146, doi:10.1099/mic.0.26170-0, 2003.

Fennel, K., Spitz, Y. H., Letelier, R. M., Abbott, M. R., and Karl, D. M.: A deterministic model for $\mathrm{N}_{2}$ fixation at stn. ALOHA in the subtropical North Pacific Ocean, Deep-Sea Res. Pt. II, 49, 149-174, 2001.

Garcia, N., Raimbault, P., and Sandroni, V.: Seasonal nitrogen fixation and primary production in the Southwest Pacific: nanoplankton diazotrophy and transfer of nitrogen to picoplankton organisms, Mar. Ecol.-Prog. Ser., 343, 25-33, doi:10.3354/meps06882, 2007.

Glibert, P. M. and Bronk, D. A.: Release of dissolved organic nitrogen by marine diazotrophic cyanobacteria, Trichodesmium spp., Appl. Environ. Microbiol., 60, 3996-4000, 1994.

Goebel, N. L., Edwards, C. A., Church, M. J., and Zehr, J. P.: Modeled contributions of three types of diazotrophs to nitrogen fixation at Station ALOHA, ISME J., 1, 606-619, 2007.

Graziano, L., Geider, R., Li, W., and Olaizola, M.: Nitrogen limitation of North Atlantic phytoplankton: Analysis of physiological condition in nutrient enrichment experiments, Aquat. Microb. Ecol., 11, 53-64, 1996.

Grimaud, G. M., Dron, A., Rabouille, S., Sciandra, A., and Bernard, O.: Modelling light-dark regime influence on the carbon-nitrogen metabolism in a unicellular diazotrophic cyanobacterium, in: CAB, 2013. 
Gruber, N. and Galloway, J. N.: An Earth-system perspective of the global nitrogen cycle, Nature, 451, 293-296, doi:10.1038/nature06592, 2008.

Hewson, I., Govil, S. R., Capone, D. G., Carpenter, E. J., and Fuhrman, J. A.: Evidence of Trichodesmium viral lysis and potential significance for biogeochemical cycling in the oligotrophic ocean, Aquat. Microb. Ecol., 36, 1-8, 2004.

Hunt, B. P. V., Bonnet, S., Berthelot, H., Conroy, B. J., Foster, R. A., and Pagano, M.: Contribution and pathways of diazotrophderived nitrogen to zooplankton during the VAHINE mesocosm experiment in the oligotrophic New Caledonia lagoon, Biogeosciences, 13, 3131-3145, doi:10.5194/bg-13-3131-2016, 2016.

Karl, D. and Letelier, R.: Nitrogen fixation-enhanced carbon sequestration in low nitrate, low chlorophyll seascapes, Mar. Ecol.Prog. Ser., 364, 257-268, doi:10.3354/meps07547, 2008.

Karl, D. M., Bates, N. R., Emerson, S., Harrison, P. J., Jeandel, C., Llinâs, O., Liu, K.-K., Marty, J.-C., Michaels, A. F., Miquel, J. C., Neuer, S., Nojiri, Y., and Wong, C. S.: Temporal Studies of Biogeochemical Processes Determined from Ocean Time-Series Observations During the JGOFS Era, in: Ocean Biogeochemistry, edited by: Fasham, M. J. R., Springer Berlin Heidelberg, Berlin, Heidelberg, 239-267, 2003.

Karl, D. M., Church, M. J., Dore, J. E., Letelier, R. M., and Mahaffey, C.: Predictable and efficient carbon sequestration in the North Pacific Ocean supported by symbiotic nitrogen fixation, P. Natl. Acad. Sci. USA, 109, 1842-1849, 2012.

Knapp, A. N., Fawcett, S. E., Martínez-Garcia, A., Leblond, N., Moutin, T., and Bonnet, S.: Nitrogen isotopic evidence for a shift from nitrate- to diazotroph-fueled export production in the VAHINE mesocosm experiments, Biogeosciences, 13, 46454657, doi:10.5194/bg-13-4645-2016, 2016.

Konno, U., Tsunogai, U., Komatsu, D. D., Daita, S., Nakagawa, F., Tsuda, A., Matsui, T., Eum, Y.-J., and Suzuki, K.: Determination of total $\mathrm{N}_{2}$ fixation rates in the ocean taking into account both the particulate and filtrate fractions, Biogeosciences, 7, 2369-2377, doi:10.5194/bg-7-2369-2010, 2010.

Leblanc, K., Cornet, V., Caffin, M., Rodier, M., Desnues, A., Berthelot, H., Turk-Kubo, K., and Heliou, J.: Phytoplankton community structure in the VAHINE MESOCOSM experiment, Biogeosciences Discuss., doi:10.5194/bg-2015-605, in review, 2016.

Luo, Y.-W., Doney, S. C., Anderson, L. A., Benavides, M., BermanFrank, I., Bode, A., Bonnet, S., Boström, K. H., Böttjer, D., Capone, D. G., Carpenter, E. J., Chen, Y. L., Church, M. J., Dore, J. E., Falcón, L. I., Fernández, A., Foster, R. A., Furuya, K., Gómez, F., Gundersen, K., Hynes, A. M., Karl, D. M., Kitajima, S., Langlois, R. J., LaRoche, J., Letelier, R. M., Marañón, E., McGillicuddy Jr., D. J., Moisander, P. H., Moore, C. M., Mouriño-Carballido, B., Mulholland, M. R., Needoba, J. A., Orcutt, K. M., Poulton, A. J., Rahav, E., Raimbault, P., Rees, A. P., Riemann, L., Shiozaki, T., Subramaniam, A., Tyrrell, T., TurkKubo, K. A., Varela, M., Villareal, T. A., Webb, E. A., White, A. E., Wu, J., and Zehr, J. P.: Database of diazotrophs in global ocean: abundance, biomass and nitrogen fixation rates, Earth Syst. Sci. Data, 4, 47-73, doi:10.5194/essd-4-47-2012, 2012.

Mahaffey, C., Michaels, A. F., and Capone, D. G.: The conundrum of marine $\mathrm{N}_{2}$ fixation, Am. J. Sci., 305, 546-595, 2005.

Mauriac, R., Moutin, T., and Baklouti, M.: Accumulation of DOC in Low Phosphate Low Chlorophyll (LPLC) area: is it related to higher production under high $\mathrm{N}: \mathrm{P}$ ratio?, Biogeosciences, 8 , 933-950, doi:10.5194/bg-8-933-2011, 2011.

Monteiro, F. M., Follows, M. J., and Dutkiewicz, S.: Distribution of diverse nitrogen fixers in the global ocean: diverse nitrogen fixers in global ocean, Global Biogeochem. Cy., 24, GB3017, doi:10.1029/2009GB003731, 2010.

Monteiro, F. M., Dutkiewicz, S., and Follows, M. J.: Biogeographical controls on the marine nitrogen fixers: controls on marine nitrogen fixers, Global Biogeochem. Cy., 25, GB2003, doi:10.1029/2010GB003902, 2011.

Moore, C. M., Mills, M. M., Langlois, R., Milne, A., Achterberg, E. P., La Roche, J., and Geider, R. J.: Relative influence of nitrogen and phosphorous availability on phytoplankton physiology and productivity in the oligotrophic subtropical North Atlantic Ocean, Limnol. Oceanogr., 53, 291-305, doi:10.4319/lo.2008.53.1.0291, 2008.

Moore, C. M., Mills, M. M., Arrigo, K. R., Berman-Frank, I., Bopp, L., Boyd, P. W., Galbraith, E. D., Geider, R. J., Guieu, C., Jaccard, S. L., Jickells, T. D., La Roche, J., Lenton, T. M., Mahowald, N. M., Marañón, E., Marinov, I., Moore, J. K., Nakatsuka, T., Oschlies, A., Saito, M. A., Thingstad, T. F., Tsuda, A., and Ulloa, O.: Processes and patterns of oceanic nutrient limitation, Nat. Geosci., 6, 701-710, doi:10.1038/ngeo1765, 2013.

Moore, J. K., Doney, S. C., Glover, D. M., and Fung, I. Y.: Iron cycling and nutrient-limitation patterns in surface waters of the World Ocean, Deep-Sea Res. Pt. II, 49, 463-507, 2001a.

Moore, J. K., Doney, S. C., Kleypas, J. A., Glover, D. M., and Fung, I. Y.: An intermediate complexity marine ecosystem model for the global domain, Deep-Sea Res. Pt. II, 49, 403-462, $2001 \mathrm{~b}$.

Moore, J. K., Doney, S. C., and Lindsay, K.: Upper ocean ecosystem dynamics and iron cycling in a global three-dimensional model: global ecosystem-biogeochemical model, Global Biogeochem. Cy., 18, GB4028, doi:10.1029/2004GB002220, 2004.

Morel, A.: Optical modeling of the upper ocean in relation to its biogenous matter content (case I waters), J. Geophys. Res.-Oceans, 93, 10749-10768, doi:10.1029/JC093iC09p10749, 1988.

Moutin, T., Van Den Broeck, N., Beker, B., Dupouy, C., Rimmelin, P., and Le Bouteiller, A.: Phosphate availability controls Trichodesmium spp. biomass in the SW Pacific Ocean, Mar. Ecol.Prog. Ser., 297, 15-21, 2005.

Moutin, T., Karl, D. M., Duhamel, S., Rimmelin, P., Raimbault, P., Van Mooy, B. A. S., and Claustre, H.: Phosphate availability and the ultimate control of new nitrogen input by nitrogen fixation in the tropical Pacific Ocean, Biogeosciences, 5, 95-109, doi:10.5194/bg-5-95-2008, 2008.

Mulholland, M. R., Bernhardt, P. W., Heil, C. A., Bronk, D. A., and O'Neil, J. M.: Nitrogen fixation and release of fixed nitrogen by Trichodesmium spp. in the Gulf of Mexico, Limnol. Oceanogr., 51, 1762-1776, 2006.

O'Neil, J. and Roman, M.: Marine Pelagic Cyanobacteria: Trichodesmium and other Diazotrophs, Grazers and associated organisms of Trichodesmium, Springer, Netherlands, 1992.

O’Neil, J. M., Metzler, P. M., and Glibert, P. M.: Ingestion of ${ }^{15} \mathrm{~N}_{2-}$ labelled Trichodesmium spp. and ammonium regeneration by the harpacticoid copepod Macrosetella gracilis, Mar. Biol., 125, 8996, doi:10.1007/BF00350763, 1996.

Ouillon, S., Douillet, P., Lefebvre, J., Le Gendre, R., Jouon, A., Bonneton, P., Fernandez, J., Chevillon, C., Magand, O., 
Lefèvre, J., Le Hir, P., Laganier, R., Dumas, F., Marchesiello, P., Bel Madani, A., Andréfouët, S., Panché, J., and Fichez, R.: Circulation and suspended sediment transport in a coral reef lagoon: The south-west lagoon of New Caledonia, Mar. Pollut. B., 61, 269-296, doi:10.1016/j.marpolbul.2010.06.023, 2010.

Pakulski, J. D. and Benner, R.: Abundance and distribution of carbohydrates in the ocean, Limnol. Oceanogr., 39, 930-940, doi:10.4319/lo.1994.39.4.0930, 1994.

Rabouille, S., Staal, M., Stal, L. J., and Soetaert, K.: Modeling the Dynamic Regulation of Nitrogen Fixation in the Cyanobacterium Trichodesmium sp., Appl. Environ. Microbiol., 72, 3217-3227, doi:10.1128/AEM.72.5.3217-3227.2006, 2006.

Raimbault, P. and Garcia, N.: Evidence for efficient regenerated production and dinitrogen fixation in nitrogen-deficient waters of the South Pacific Ocean: impact on new and export production estimates, Biogeosciences, 5, 323-338, doi:10.5194/bg-5323-2008, 2008.

Reddy, K. J., Haskell, J. B., Sherman, D. M., and Sherman, L. A.: Unicellular, aerobic nitrogen-fixing cyanobacteria of the genus Cyanothece, J. Bacteriol., 175, 1284-1292, 1993.

Rodier, M. and Le Borgne, R.: Population dynamics and environmental conditions affecting Trichodesmium spp.(filamentous cyanobacteria) blooms in the south-west lagoon of New Caledonia, J. Exp. Mar. Biol. Ecol., 358, 20-32, 2008.

Rodier, M. and Le Borgne, R.: Population and trophic dynamics of Trichodesmium thiebautii in the SE lagoon of New Caledonia. Comparison with T. erythraeum in the SW lagoon, Mar. Pollut. B., 61, 349-359, doi:10.1016/j.marpolbul.2010.06.018, 2010.

Roenneberg, T. and Carpenter, E. J.: Daily rhythm of $\mathrm{O}_{2}$ evolution in the cyanobacterium Trichodesmium thiebautii under natural and constant conditions, Mar. Biol., 117, 693-697, doi:10.1007/BF00349782, 1993.

Sohm, J. A., Edwards, B. R., Wilson, B. G., and Webb, E. A.: Constitutive Extracellular Polysaccharide (EPS) Production by Specific Isolates of Crocosphaera watsonii, Front. Microbiol., 2, 229, doi:10.3389/fmicb.2011.00229, 2011.

Subramaniam, A., Yager, P. L., Carpenter, E. J., Mahaffey, C., Björkman, K., Cooley, S., Kustka, A. B., Montoya, J. P., SañudoWilhelmy, S. A., Shipe, R., and Capone, D. G.: Amazon River enhances diazotrophy and carbon sequestration in the tropical North Atlantic Ocean, P. Natl. Acad. Sci. USA, 105, 1046010465, doi:10.1073/pnas.0710279105, 2008.

Tanaka, T. and Rassoulzadegan, F.: Full-depth profile $(0-2000 \mathrm{~m})$ of bacteria, heterotrophic nanoflagellates and ciliates in the NW Mediterranean Sea: Vertical partitioning of microbial trophic structures, Deep-Sea Res. Pt. II, 49, 2093-2107, doi:10.1016/S0967-0645(02)00029-2, 2002.
Tanaka, T., Thingstad, T. F., Christaki, U., Colombet, J., CornetBarthaux, V., Courties, C., Grattepanche, J.-D., Lagaria, A., Nedoma, J., Oriol, L., Psarra, S., Pujo-Pay, M., and Van Wambeke, F.: Lack of P-limitation of phytoplankton and heterotrophic prokaryotes in surface waters of three anticyclonic eddies in the stratified Mediterranean Sea, Biogeosciences, 8, 525-538, doi:10.5194/bg-8-525-2011, 2011.

Thingstad, T. F., Krom, M. D., Mantoura, R. F. C., Flaten, G. F., Groom, S., Herut, B., Kress, N., Law, C. S., Pasternak, A., Pitta, P., Psarra, S., Rassoulzadegan, F., Tanaka, T., Tselepides, A., Wassmann, P., Woodward, E. M. S., Wexels Riser, C., Zodiatis, G., and Zohary: Nature of phosphorus limitation in the ultraoligotrophic eastern Mediterranean, Science, 309, 1068-1071, 2005.

Turk-Kubo, K. A., Frank, I. E., Hogan, M. E., Desnues, A., Bonnet, S., and Zehr, J. P.: Diazotroph community succession during the VAHINE mesocosm experiment (New Caledonia lagoon), Biogeosciences, 12, 7435-7452, doi:10.5194/bg-12-7435-2015, 2015.

Van Wambeke, F., Bonnet, S., Moutin, T., Raimbault, P., Alarcón, G., and Guieu, C.: Factors limiting heterotrophic bacterial production in the southern Pacific Ocean, Biogeosciences, 5, 833845, doi:10.5194/bg-5-833-2008, 2008.

Van Wambeke, F., Pfreundt, U., Barani, A., Berthelot, H., Moutin, T., Rodier, M., Hess, W. R., and Bonnet, S.: Heterotrophic bacterial production and metabolic balance during the VAHINE mesocosm experiment in the New Caledonia lagoon, Biogeosciences, 13, 3187-3202, doi:10.5194/bg-13-3187-2016, 2016.

Verity, P. G., Robertson, C. Y., Tronzo, C. R., Andrews, M. G., Nelson, J. R., and Sieracki, M. E.: Relationships between cell volume and the carbon and nitrogen content of marine photosynthetic nanoplankton, Limnol. Oceanogr., 37, 1434-1446, 1992.

Villareal, T. A., Woods, S., Moore, J. K., and CulverRymsza, K.: Vertical migration of Rhizosolenia mats and their significance to $\mathrm{NO}_{3}^{-}$fluxes in the central North Pacific gyre, J. Plankton Res., 18, 1103-1121, 1996.

Zohary, T., Herut, B., Krom, M. D., Fauzi C. Mantoura, R., Pitta, P., Psarra, S., Rassoulzadegan, F., Stambler, N., Tanaka, T., Frede Thingstad, T., Malcolm, S., and Woodward, E.: P-limited bacteria but $\mathrm{N}$ and $\mathrm{P}$ co-limited phytoplankton in the Eastern Mediterranean - a microcosm experiment, Deep-Sea Res. Pt. II, 52, 3011-3023, doi:10.1016/j.dsr2.2005.08.011, 2005. 